\title{
Promoting Fair Private Governance in the Platform Economy: EU Competition and Contract Law Applied to Standard Terms
}

\author{
Jacobien RUTGERS and Wolf SAUTER*
}

\begin{abstract}
In recent years, a platform economy has emerged that is dominated by undertakings such as Google, Amazon, Facebook, Apple, and Microsoft. They have established a form of private governance vis-à-vis their consumers and customers by means of standard terms that create a risk of exploitation. This trend clashes with the internal market effort of the EU that is predicated on consumer rights and fair competition to address market failures such as market power, information asymmetry, and asymmetrical contractual dependency. In this article we examine how the resulting tensions can be addressed by means of EU competition and contract law. This is based on enforcing fairness by requiring (1) the implementation of proportionality-balancing interests - and (2) respect of the duty of care, in the sense of compliance by design. Jointly this can be seen as an expression of accountability that needs to be made explicit. Apart from pre-existing case law and legislation, we take into account the December 2020 Commission proposals for platform regulation, as well as behavioural insights into consumer behaviour.
\end{abstract}

Keywords: consumer protection, competition law, platform regulation

\section{INTRODUCTION}

\section{A. Origins of and Reasons for Standard Terms}

The industrial revolution alongside mass production of goods and eventually services also introduced mass contracting. This in turn resulted in pre-drafted contracts in the form of standard terms. ${ }^{1}$ This development has gradually changed the perception of contracts and contract law. Freedom of contract or party autonomy

\footnotetext{
* Jacobien Rutgers is professor of European private law and Wolf Sauter is professor of law, markets and behaviour, both at the Vrije Universiteit (VU) Amsterdam. Wolf Sauter also works at the Dutch Authority for Consumers and Markets (ACM). This article was written in a private capacity. We are grateful for comments from Hugh Collins, Inge Graef, Xavier Groussot, Giorgio Monti, and Martijn Snoep, and for research assistance by Lisa van Geel.

1 See for instance: F Kessler, 'Contracts of Adhesion - Some Thoughts about Freedom of Contract' (1943) 43 Columbia Law Review 629, p 631; M J Radin, Boilerplate, the Fine Print, Vanishing Rights, and the Rule of Law (Princeton University Press, 2014).
} 
is the point of departure of classic contract law: following negotiations, parties enter into a contract that is assumed to serve their mutual interests best. As the outcome of negotiations, the contract was originally presumed to be fair as such. ${ }^{2}$ With respect to the French Code Civil of 1804, this was expressed as qui dit contractuel dit juste. ${ }^{3}$

In modern contract law however it has been recognised that often contracts are concluded without negotiations, and that even if negotiations take place, they do not always result in a fair outcome. ${ }^{4}$ As a result, in the EU context as elsewhere, in the second half of the twentieth century legislation was adopted to protect weaker contract parties, primarily (but not exclusively) consumers, against unilaterally drafted standard terms.

\section{B. Standard Terms and Digital Platforms}

Moreover, the notions of contract and contract law are increasingly under pressure from the platform economy. Digital platforms use contracts and standard terms in a different manner from what is described in textbooks on contract law. ${ }^{5}$ To construct a legal framework for their services, digital platforms enter into contracts with various types of customers in multi-sided markets, where one side of the market may for example represent end users of social media services and the other advertisers, respectively app users versus app developers.

In both markets the terms of these contracts are rarely negotiated: instead, platforms draft standard terms unilaterally. These terms are intended to apply regardless of where a customer lives or is established, although sometimes they are slightly modified if required by applicable law. ${ }^{6}$ They concern, inter alia, exclusions of liability, modification of standard terms, forum choice, choice of law, providing a license to the platform to use the user's content anywhere and anytime, entitling the platform to use and sell the user's data, and charging a commission for use of the platform. ${ }^{7}$

Much of the interpretation and application of these rules is administered by the digital platform itself to enforce compliance with its private regulatory regime. In addition, the platform often controls the content of the contract between the end-user

\footnotetext{
2 P Atiyah, The Rise and Fall of Freedom of Contract (Clarendon Press, 1979), pp $681 \mathrm{ff}$.

3 M Fabre-Magnan, Droits des obligations, 1 - Contrat et engagement unilateral (Presses Universitaires de France, 2019), No 29 (who quotes the French nineteenth-century lawyer Fouillée).

4 Atiyah, note 2 above, pp 726 ff; M Hesselink, CFR \& Social Justice, Sellier (European Law Publishers, 2008), p 13.

5 P Iamiceli, 'Online Platforms and the Digital Turn in EU Contract Law: Unfair Practices, Transparency and the (Pierced) Veil of Digital Immunity' (2019) 15 European Review of Contract 392, pp 394 ff; A Orti Vallejo, 'Contractual Relationships in Collaborative Economy Platforms' (2019) 5 European Review of Private Law 995.

6 D Wielsch, 'Global Law's Toolbox: How Standards Form Contracts' (2012) 60 The American Journal of Comparative Law 1075.

7 See in this respect, M Loos and J Luzak, Update the Unfair Contract Terms Directive for Digital Services (Study Requested by European Parliament's Committee on Legal Affairs, 2021), ch 2.
} 
and the business offering the goods or service as well. ${ }^{8}$ For instance, at the outset of the COVID-19 crisis, hospitality platform Airbnb notified guests on this basis that they could freely cancel certain reservations for stays with their individual hosts before a certain date that had been booked using Airbnb. ${ }^{9}$ The degree of control exercised at this level differs from platform to platform.

Consequently, the regimes that platforms establish by means of their standard terms form a type of private governance, in the sense of a largely unilateral regime based on private law. ${ }^{10}$ In our view, (1) as is the case for standard terms more generally, this should be treated differently from more balanced contracts between peers that are the result of negotiations, and (2) as we will see below, possibly requires additional controls compared to non-platforms as well because of the greater degree of control over their contracting parties that is associated with the digital platforms due to lock-in, asymmetrical contractual dependence, and information asymmetry.

\section{EU Competition and Contract Law}

These areas of law both serve to protect consumers, although they do so from a different perspective. ${ }^{11}$ Whereas competition law looks at market power and the degree of competition in markets as a whole, consumer law in principle concerns contractual power in individual transactions. There are also some commonalities. Both share a concern about possible harm to consumer welfare that may result from imbalances that are due to asymmetrical market positions. However, only competition law has a category of rules (the prohibition on dominance abuse) that are formally based on a specific degree of market power-although enforcement priorities in contract

8 Iamiceli, note 5 above, pp $404 \mathrm{ff}$.

9 'Extenuating Circumstances Policy and the Coronavirus (COVID-19)' (Airbnb.com, 1 October 2020), https://www.airbnb.co.uk/help/article/2701/extenuating-circumstances-policy-and-the-coronavirus- covid19?_set_bev_on_new_domain=1617111737_NzUwOGJlMWRhM2Y3. Platforms also require users to use the platform's payment service with respect to the contract concluded between the platform's users.

10 A Metzger, 'Standard Form Contracts as Private Law Regimes' in H Eidenmüller (ed) Regulatory Competition in Contract Law and Dispute Resolution (C.H.Beck, 2013), pp 112-15; S Grundmann and P Hacker, 'The Digital Dimension as a Challenge to European Contract Law - the Architecture' in S Grundmann (ed) European Contract Law in a Digital Age (Intersentia, 2018), pp 22 ff; E Stringham, Private Governance: Creating Order in Economic and Social Life (Oxford University Press, 2015); D Wielsch, 'Private Law Regulation of Digital Intermediaries' (2019) 2 European Review of Private Law 197. For a different perspective, see P Jacek Palka, 'Terms of Service Are Not Contracts - Beyond Contract Law in The Regulation of Online Platforms' in Grundmann, note 10 above. In relation to soft law, see C Scott, F Cafaggi, and L Senden (eds), The Challenge of Transnational Private Regulation: Conceptual and Constitutional Debates (Wiley/Blackwell, 2011).

11 H Collins, 'Good Faith in European Contract Law' (1994) 14 Oxford Journal of Legal Studies 292; M Huffman, 'Bridging the Divide? Theories for Integrating Competition Law and Consumer Protection' (2010) 6 European Competition Journal 7; K Cseres, Competition Law and Consumer Protection (Kluwer Law International, 2005); G Monti, 'The Revision of the Consumer Acquis from a Competition Law Perspective' (2007) 3 European Review of Contract Law 295. 
law may take a comparable position in practice. ${ }^{12}$ Both are enforced by public authorities as well as, at least in theory, by means of private enforcement (which in EU competition law is largely limited to damages actions). In Europe, authorities such as the Autorità Garante della Concorrenza e il Mercato ('AGCM') in Italy, the Consumer and Markets Authority ('CMA') in the UK, and the Authority for Consumers and Markets ('ACM') in the Netherlands combine the relevant public enforcement functions.

Competition law is most relevant to our topic regarding the prohibition on abuse of dominance that serves to control the exercise of market power ex post. The abuse of dominance test requires establishing a dominant position within a so-called relevant market, and proving a specific abuse, subject to objective justification and efficiency defences that can be raised by the undertaking concerned. It is relevant specifically where, until recently more rarely, it counteracts exploitation directly. ${ }^{13}$ The alternative, combating exclusion of competitors under dominance abuse only indirectly protects consumers by protecting competition, which was the prevalent approach. The most relevant exploitative abuse in this context is imposing unfair contract terms as spelled out in Article 102a of the Treaty on the Functioning of the European Union ('TFEU'). 14

Such direct control of dominant platforms' conditions has been relatively rare, albeit on the increase with recent cases in Germany (notably the well-reported Facebook case), France, and the Netherlands, as well as at EU level. These are discussed below in relation to both sides of the market: business using platforms to provide products and services, and consumers procuring these products and services from them via digital platforms.

In EU contract law there is more elaborate legislation that sets out specific protection. These rules are adopted within the context of the establishment and proper functioning of the internal market. So far, private governance through standard terms is primarily policed by national legislation that transposes Directive 93/13 on unfair terms in consumer contracts ('UCTD'). ${ }^{15}$ Under the UCTD, unfair terms in business to consumer ('B2C') contracts which parties have not negotiated are non-binding, or

\footnotetext{
12 I Graef and S van Berlo, 'Towards Smarter Regulation in the Areas of Competition, Data Protection and Consumer Law: Why Greater Power Should Come with Greater Responsibility' (2020) 12 European Journal of Risk Regulation 1, https://doi.org/10.1017/err.2020.92.

13 Excessive pricing cases have recently become the main category of such exploitative abuses, so far mainly concerning pharmaceuticals: Aspen Pharma, A480, No 26185, Decision of the AGCM of 29 September 2016, confirmed by the Tribunale Amministrativo Regionale del Lazio, 26 July 2017, No 8948/2017; Pfizer and Flynn Decision of the CMA of 7 December 2016, Court of Appeal (2020) EWCA Civ 339, No C3/2018/1847\&1874, CMA v Pfizer/Flynn, 10 March 2020; CD Pharma Decision by Danish Konkurrence- og Forbrugerstyrelsen of 31 January 2018, confirmed on 2 March 2020 by the Sø- og Handelsretten Dom (BS-3038/2019-SHR); Case AT.40394 - Aspen Commitments to the European Commission 28 January 2021.

14 Article 102a TFEU states that 'Such abuse may, in particular, consist in: (a) directly or indirectly imposing unfair purchase or selling prices or other unfair trading conditions'.

15 Council Directive 93/13/EEC of 5 April 1993 on unfair terms in consumer contracts (UCTD), OJ 1993, L95/29.
} 
in other words void. The European Court of Justice has introduced the rational or average consumer as yardstick for the unfairness test under the UCTD. ${ }^{16}$ Although as we will see, the behavioural literature questions whether rational consumers exist at all. ${ }^{17}$

We will also look at the online intermediation Regulation 2019/1150, which does not aim to protect consumers but businesses that offer their goods and services to consumers in the European Union through a platform (platform to business, or 'P2B'). ${ }^{18}$ The P2B Regulation aims to achieve a 'fair, predictable, sustainable and trusted online business environment in the internal market' through mandatory rules that provide transparency and effective redress mechanisms. ${ }^{19}$ Jointly this is the relevant EU contract law, looking at both sides of the market. In this paper we will not take into account consumer and other protection provided by conflict rules if the contract involves a cross-border situation. Moreover, we will not consider the data protection rules.

Below we will examine whether there is any degree of convergence between EU competition and contract law with regard to standard terms. More specifically we examine how public and private law concepts of fairness are applied to standard terms in this context to redress imbalances in bargaining power.

\section{Adjacent Regulation}

In addition, we will consider how fairness is interpreted in the EU's digital strategy ${ }^{20}$ notably the European Commission's December 2020 proposals for a Digital Markets Act to control the market behaviour of platforms designated as gatekeepers based on turnover thresholds and a Digital Services Act that imposes certain policing duties on platforms providing access to digital content. ${ }^{21}$ These rules, once adopted, will

16 A Kásler H Káslerné Rábai v Otp Jelzálogbank Zrt (Kásler v Jelzálogbank), C-26/13, ECLI:EU: C:2014:282, Judgment of 30 April 2014; H Schebesta and K Purnhagen, 'Island or Ocean: Empirical Evidence on the Average Consumer Concept in the UCPD' (2020) 2 European Review of Private Law 293, p 298.

17 Schebesta and Purnhagen, note 16 above.

18 Regulation (EU) 2019/1150 of the European Parliament and of the Council of 20 June 2019 on promoting fairness and transparency for business users of online intermediation services (P2B), OJ 2019, L186/57. The regulation also covers search engines but because the relation between businesses and companies that runs a search engine is not contractual, we will not discuss them. See also Directive (EU) 2019/633 of the European Parliament and of the Council of 17 April 2019 on unfair trading practices in business-to-business relationships in the agricultural and food supply chain, OJ 2019, L111/59.

19 Regulation 2019/1150 (P2B), note 18 above, Rec 7.

20 'Shaping Europe's Digital Future', Communication from the Commission, 19 February 2020, https://ec.europa.eu/info/publications/communication-shaping-europes-digital-future_en.

${ }^{21}$ COM/2020/842 final, Proposal for a Regulation of the European Parliament and of the Council on contestable and fair markets in the digital sector (Digital Markets Act) (15 December 2020); COM/ 2020/825 final, Proposal for a Regulation of the European Parliament and of the Council on a Single Market for Digital Services (Digital Services Act) and amending Directive 2000/31/EC (15 December 2020). 
constitute a separate regulatory framework that applies in parallel to EU competition and contract law. Hence, we will look into the relevance of especially the Digital Markets Act both in terms of its content, as well as in terms of its impact on the enforcement of competition and contract law regarding digital platforms' standard terms.

\section{E. The Behavioural Dimension}

As was mentioned above, a behavioural approach to the interaction between consumer psychology and market forces vis-à-vis standard terms points out that it is not realistic and therefore undesirable to rely on rational consumers. Consumers may discount risks inherent in unbalanced contract terms due to over-optimism and a limited and short term focus (myopia), or due to the availability heuristic (the perceived infrequence of adverse events based on the experience of the subject), and due to status quo and omission biases may fail to switch even where clearly superior alternatives exist. ${ }^{22}$ By using complex contract and cost deferral (such as low initial payments), businesses make the most of the interaction between consumer psychology and market forces in a manner that increases consumer risk. ${ }^{23}$ We will examine their implications for fairness in the application of EU competition and contract law to digital platforms' standard terms. ${ }^{24}$

\section{F. Research Questions}

A contract that consists of standard terms is therefore a way of construing private governance. Our starting point is that fairness norms of contract law may be used to discipline private governance, just as competition law may be able to. More specifically we examine how public and private law concepts of fairness are applied

22 E Zamir and D Teichman, Behavioral Law and Economics (Oxford University Press, 2018), pp 301-06; O Bar-Gill, 'Consumer Transactions' in E Zamir and D Teichman (eds), The Oxford Handbook of Behavioral Economics and the Law (Oxford University Press, 2014); O Bar-Gill and O Ben-Sharar, 'Regulatory Techniques in Consumer Law Protection: A Critique of European Consumer Contract Law' (2013) 50 Common Market Law Review 1; A Tor, 'Justifying Competition Law in the Face of Consumers' Bounded Rationality' in K Mathis and A Tor (eds), New Developments in Competition Law and Economics (Springer, 2019).

23 Bar-Gill, note 22 above, pp $467 \mathrm{ff}$.

24 As an aside, the relationship between a digital platform and its customers is not only determined by the standard terms, but increasingly also by the algorithms which the platform uses to provide and refine its services. These algorithms, which may deliberately exploit consumer biases, are coded by the platform and form part of its business model, but so far generally remain outside the scope of regulation and antitrust. They will also remain outside the scope of the present article. On competition concerns in this regard, see S Assad, R Clark, D Ershov, and L Xu, Algorithmic Pricing and Competition: Empirical Evidence from the German Retail Gasoline Market (CESifo Working Papers, 2020), No 8521. On manipulation of consumers in this respect, see R Calo and A Rosenblatt, 'The Taking Economy: Uber, Information, and Power' (2017) 117 Columbia Law Review 1623; S Becher and S Dadush, 'Relationship as Product: Transacting in the Age of Loneliness' (forthcoming 2021) University of Illinois Law Review. 
to standard terms to redress imbalances in bargaining power in this context. The main question we wish to address in this paper is therefore whether there is convergence between the developing fairness norms in EU competition and contract law with regard to the control of private governance by means of standard terms. A secondary issue is how these norms can be enforced effectively, and what behavioural modifications are required from digital platforms.

Below, we will first deal with the relevant rules and cases in competition law and discuss the recent proposals for regulation of digital platforms. Next we look at EU contract law, and finally at the implications of behavioural insights.

\section{FAIRNESS, COMPETITION LAW, AND DIGITAL PLATFORMS STANDARD TERMS}

Although in law the concept of fairness is used frequently, it has not been uniformly defined. Its meaning ranges from more practical notions of equity - a fair share - to the theoretical foundations of justice itself. ${ }^{25}$ Unsurprisingly therefore, fairness in competition law is a contested topic in its own right. ${ }^{26}$ It has been parsed in procedural and substantive dimensions, and the latter in different horizontal and vertical spheres, ${ }^{27}$ as well as according to various types of intervention. ${ }^{28}$

Especially the distinction between procedural fairness-due process - and substantive fairness in terms of outcome is significant here. Commentators universally subscribe to the former albeit often focusing on rights of the defence instead while ignoring procedural fairness obligations for undertakings enjoying market power and fairness rights for their victims. The latter, substantive fairness, is considered more problematic because it challenges efficiency as the guiding light of competition law, and by definition includes distributional concerns, even if the consumer tends to remain at centre stage. Competition Commissioner Vestager has made fairness a

25 Ranging from Aristotle's Nichomanean Ethics to John Rawls's Theory of Justice. Erin Kelly (ed), John Rawls, Justice as Fairness: A Restatement (Belknap Press, 2001).

26 N Dunne, 'Fairness and the Challenge of Making Markets Work Better' (2020) 83 Modern Law Review 230; D Gerard, A Komninos, and D Waelbroeck (eds), Fairness in EU Competition Policy: Significance and Implications: An Inquiry into the Soul and Spirit of Competition Enforcement in Europe (Bruylant, 2020); A Ayal, Fairness in Antitrust: Protecting the Strong from the Weak (Hart, 2014).

27 M Trebilcock and F Ducci, 'The Multifaceted Nature of Fairness in Competition Policy' (2017) 1 CPI Antitrust Chronicle 1.

28 A Ezrachi, The Goals of EU Competition Policy and the Digital Economy (Oxford Legal Studies Research Paper No 2018/17 and BEUC Discussion Paper No 2018/71), https://www.beuc.eu/publications/beuc-x-2018-071_goals_of_eu_competition_law_and_digital_economy.pdf, groups six types of intervention under fairness: (1) counteracting unfair market practice or illegitimate wealth transfers; (2) intervening against discrimination by dominant undertakings; (3) counteracting misleading information; (4) counteracting extreme instances of asymmetric information; (5) fighting unfair handling of data, and violations of data protection and privacy rights; and (6) imposing a fiduciary duty requiring ethical handling of data. 
leading theme of her term in office, focusing on a fair deal for consumers. ${ }^{29}$ Former director general of DG Competition Laitenberger (now a Court of Justice of the European Union ('CJEU') Judge) has concentrated instead on due process. ${ }^{30}$

This implies that the fairness discourse in EU competition law is gaining traction. Yet the concept of fair competition is not new. It is part of the preamble of the TFEU. ${ }^{31}$ Fairness also appears in both legs of EU competition law: in the provision that provides a legal exception to the cartel prohibition and as part of the prohibition on the abuse of a dominant position.

Article 101(3) TFEU requires a fair share for consumers of the benefits of otherwise anticompetitive agreements before they can benefit from this exception. Most significantly for our current perspective on standard terms of digital platforms, it also features in Article 102a TFEU in relation to the prohibition of both unfair prices and unfair trading conditions for dominant undertakings.

More recently, the $2019 \mathrm{ECN}+$ Directive that harmonises the powers of competition authorities in the EU states its objective as the creation of fairer and more open competitive markets. ${ }^{32}$ As we will see below the December 2020 proposal for a Digital Markets Act aims at contestable and fair markets. Both imply that competition alone is not enough, but that fair outcomes matter as well. As far as EU competition policy is concerned there appears to be an increasing emphasis not just on fairness in an abstract sense, but on substantive fairness that is in line with a more general trend toward a plurality of goals of competition law beyond consumer welfare and efficiency. ${ }^{33}$

It is hard to read across from general fairness to the specific fairness norms embedded in the TFEU. In this article, we will focus not on various theories of fairness in competition law, although the distinction between procedural and substantive fairness appears to be useful. Instead, we will look at how fairness is and/or can be implemented in positive competition law, more in particular in relation to balancing obligations imposed on dominant undertakings as a result of their special responsibility in relation to standard terms. This means looking at how Article 102 TFEU is applied to standard terms, and which lessons may be derived from that. It is therefore Article 102, more specifically Article 102a TFEU that we will be looking at more closely.

29 M Vestager, 'Fairness and Competition', speech at GCLC Annual Conference, Brussels 25 January 2018, https://ec.europa.eu/commission/commissioners/2014-2019/vestager/announcements/fairnessand- competition_en.

30 J Laitenberger, 'Fairness in EU Competition Law Enforcement', speech at British Chamber of Commerce EU \& Belgium, Brussels, 20 June 2018, https://ec.europa.eu/competition/speeches/text/ sp2018_10_en.pdf; J Laitenberger, 'EU Competition Law in Innovation and Digital Markets: Fairness and the Consumer Welfare Perspective', speech at MLex/Hogan Lovells event, Brussels, 10 October 2017, https://ec.europa.eu/competition/speeches/text/sp2017_15_en.pdf.

31 Treaty Establishing the European Community, OJ 1992, C224/1, Title II (Preamble) states: 'Recognizing that the removal of existing obstacles calls for concerted action in order to guarantee steady expansion, balanced trade and fair competition'.

32 Directive (EU) 2019/1 of the European Parliament and of the Council of 11 December 2018 to empower the competition authorities of the Member States to be more effective enforcers and to ensure the proper functioning of the internal market, OJ 2019, L11/3, Recs 1, 6.

33 Ezrachi, note 28 above. 


\section{A. The Non-digital Case Law on Contract Terms}

First, we will briefly look back at the competition case law on standard terms that precedes the emergence of digital platforms. In summary, contract terms are considered unfair in the sense of Article 102a TFEU here if they fail to meet the twin standards of (1) necessity in relation to a legitimate objective and (2) proportionality to that objective in the sense of establishing an appropriate balance between the interests concerned. ${ }^{34}$ It is currently an open question whether one should start with the harm suffered before addressing these elements of a fair balance. This approach was initially established in a number of copyright cases, notably BRT II in $1974,{ }^{35}$ and confirmed in 2009 in der Grüne Punkt, a case regarding a system for packaging waste recycling. ${ }^{36}$

Thus, in BRT II the Court stated that

the fact that an undertaking entrusted with the exploitation of copyrights and occupying a dominant position within the meaning of Article 86 imposes on its members obligations which are not absolutely necessary for the attainment of its object and which thus encroach unfairly upon a member's freedom to exercise his copyright can constitute an abuse. $^{37}$

The Commission in GEMA interpreted this as follows:

It may ... be inferred from the BRT II case that, in an examination of a collecting society's statutes in the light of the Treaty competition rules the decisive factor is whether they exceed the limits absolutely necessary for effective protection (indispensability test) and whether they limit the individual copyright holder's freedom to dispose of his work no more than need be (equity). ${ }^{38}$

In its DSD Decision that was confirmed by the Court in der Grüne Punkt, the Commission stated concisely and unreservedly that:

Unfair commercial terms exist where an undertaking in a dominant position fails to comply with the principle of proportionality. ${ }^{39}$

\footnotetext{
34 R O'Donoghue and J Padilla, The Law and Economics of Article 102 TFEU, $3^{\text {rd }}$ ed (Hart,), pp 1033-45.

35 Belgische Radio en Televisie and société belge des auteurs, compositeurs et éditeurs v SV SABAM and NV Fonior (BRT II), 127-73, ECLI:EU:C:1974:25, Judgment of 27 March 1974.

36 Der Grüne Punkt - Duales System Deutschland GmbH v Commission, C-385/07 P, ECLI:EU: C:2009:456, Judgment of 6 July 2009.

37 BRT II, note 35 above, para 15.

38 Commission Decision IV/29.971 - GEMA statutes, of 4 December 1981, OJ 1982, L94/12, para 36.

39 Commission Decision 2001/463/EC (Case COMP D3/34493 — DSD) of 20 April 2001, OJ 2001, L166/1, para 112. Confirmed in Der Grüne Punkt - Duales System Deutschland GmbH v Commission, C-385/07 P, ECLI:EU:C:2009:456, Judgment of 6 July 2009.
} 
The proportionality standard was applied to dominant undertakings in other dominance cases as well. It appeared explicitly in United Brands in the context of a meeting competition defence by a dominant undertaking in relation to its refusal to supply (1978). ${ }^{40}$ More recently, the proportionality standard appeared implicitly in the Kanal $5(2008)^{41}$ and SABAM/Weareone.World (2020) ${ }^{42}$ cases, where it was held that the interest of purchasers in paying for their actual use of a product should be balanced with those of the dominant undertaking when it set its pricing scheme. The method of calculation should not be disproportionally reliant on charges other than actual use and can only deviate from a more accurate use-based method if necessary for the legitimate goal of the agreement and if such alternative methods are unreasonably expensive to apply. ${ }^{43}$

At the same time this appears to set a standard of manifest (and not strict) disproportionality precisely because it would still be acceptable to base the remuneration on turnover for variables other than actual use, as long as this is done in a proportional manner. This approach squares with case law like that in Höfner regarding manifest inability to meet demand, and excessive pricing cases where the price is not only high compared to a benchmark, but significantly and persistently higher. ${ }^{44}$

\section{B. The Emerging Digital Platform Case Law}

There has long been a debate about the need to tackle digital platforms by means of competition law, ${ }^{45}$ and the confluence of competition and data protection law. ${ }^{46}$

40 United Brands Company and United Brands Continentaal BV v Commission of the European Communities, 27/76, ECLI:EU:C:1978:22, Judgment of 14 February 1978, para 190: 'Even if the possibility of a counter-attack is acceptable that attack must still be proportionate to the threat taking into account the economic strength of the undertakings confronting each other'.

41 Kanal 5 Ltd and TV 4 AB v Föreningen Svenska Tonsättares Internationella Musikbyrå (STIM) upa, C-52/07 ECLI:EU:C:2008:703, Judgment of 11 December 2008, para 41.

42 Belgische Vereniging van Auteurs, Componisten en Uitgevers CVBA (SABAM) v Weareone. World $B V B A$ and Wecandance NV, C-372/19, ECLI:EU:C:2020:959, Judgment of 25 November 2020, para 60 .

43 Ibid.

44 Klaus Höfner and Fritz Elser v Macrotron GmbH, C-41, ECLI:EU:C:1991:161, /90 Judgment of the Court of 23 April 1991; Autortiesību un komunicēšanās konsultāciju aǵentūra / Latvijas Autoru apvienība v Konkurences padome, C-177/16, ECLI:EU:C:2017:689, Judgment of the Court of 14 September 2017.

45 N Petit, Big Tech \& the Digital Economy: The Moligopoly Scenario (Oxford University Press, 2020); M Walker, 'Competition Policy and Digital Platforms: Six Uncontroversial Propositions' (2020) 16 European Competition Journal 1; Ezrachi, note 28 above; C Shapiro, 'Antitrust in a Time of Populism' (2018) 61 International Journal of Industrial Organization 714.

46 F Costa-Cabral and O Lynskey, 'Family Ties: The Intersection Between Data Protection and Competition in EU Law' (2017) 54 Common Market Law Review 11; M Volmar and K Helmdach, 'Protecting Consumers and Their Data through Competition Law? Rethinking Abuse of Dominance in Light of the Federal Cartel Office's Facebook Investigation' (2018) 14 European Competition Journal 195; H Kalimo and K Majcher, 'The Concept of Fairness: Linking Competition and Data Protection Law in the Digital Marketplace' (2017) 42 European Law Review 210. 
Following a period of hibernation after the case to break up Microsoft effectively stalled and was settled by a consent decree ${ }^{47}$ digital competition cases are now taking off again in the US ${ }^{48}$ However since its own 2004 Microsoft Decision,${ }^{49}$ it has been the EU blazing the trail. ${ }^{50}$ In retrospect, the facile approach of enforcers in both systems, which led to merger clearances in cases such as Facebook/WhatsApp ${ }^{51}$ that strengthened dominance while damaging the contestability of digital markets, may now be regretted. Below we will focus on the so far limited subset of cases involving platforms and standard terms.

\section{The German Facebook Case}

The February 2019 Bundeskartellamt ('BKA') ruling against Facebook demonstrates that standard terms imposed on consumers may form an abuse of dominance. ${ }^{52}$ The BKA identified a two-sided relevant market that combined nominally free social media services for consumers with paid advertising services to business users. It found that Facebook's standard terms deny consumers choice over the use of their personal data that are collected and combined not only from Facebook itself, but from other services owned by the same company such as WhatsApp (and Instagram), as well as data gleaned from unrelated internet services. ${ }^{53}$ The BKA construed this as a form of consumer exploitation, while the resulting scale and scope of data collection led to exclusion of competitors. Both were found to constitute dominance abuse under the German competition rules. (The EU rules were not

47 United States v Microsoft Corporation, 253 F3d 34 (DC Cir 2001); settled in United States v Microsoft Corporation, Final Judgment, Civil Action No 98-1232 (CKK), (DC Cir 2002).

48 Including a lawsuit intended to break up Facebook, WhatsApp, and Instagram and vet future acquisitions to a stricter standard. M Acton and K Vasant, 'US Facebook Lawsuits Surpass Anything EU Has Tried against Big Tech' (MLex, 10 Dec 2020), https://mlexmarketinsight.com/news-hub/editors-picks/ area-of-expertise/data-privacy-and-security/us-facebook-lawsuits-surpass-anything-eu-has-triedagainst-big-tech; 'FTC Sues Facebook for Illegal Monopolization, Agency challenges Facebook's Multi-year Course of Unlawful Conduct' (FTC Press Release, 9 December 2020), https://www.ftc. gov/news-events/press- releases/2020/12/ftc-sues-facebook-illegal-monopolization.

49 Commission Decision of 24 March 2004 in Case AT 37792 (Microsoft). Confirmed in Microsoft Corp v Commission, T-201/04, ECLI:EU:T:2007:289, Judgment of 17 September 2007. The enforcement of the Decision was litigated until 2012. See C Ahlborn and D Evans, 'The Microsoft Judgment and Its Implications for Competition Policy towards Dominant Firms in Europe' (2009) 75 Antitrust Law Journal 887; P Larouche, 'The European Microsoft Case at the Crossroads of Competition Policy and Innovation: Comment on Ahlborn and Evans' (2009) 75 Antitrust Law Journal 933.

50 Notably the Google Cases: Commission Decision of 27 June 2017 in Case AT.39740 (Google Shopping); Commission Decision of 18 July 2018 in Case AT.40099 (Google Android); Commission Decision of 20 March 2019 in Case AT.40411 (Google Search).

51 Commission Decision of 4 October 2014 in Case No COMP/M.7217 (Facebook/WhatsApp).

52 BkartA, Decision of 6 February 2019, B6-22/16.

53 M Botta and K Wiedemann, 'The Interaction of EU Competition, Consumer, and Data Protection Law in the Digital Economy: The Regulatory Dilemma in the Facebook Odyssey' (2019) 64 The Antitrust Bulletin 428; J Mohr, 'Konditionenmissbrauch durch socialize Netzwerke: Facebook' (2020) 69 Wirtschaft und Wettbewerb 506. 
applied, possibly in order to remain outside the European Commission's coordination powers and as the bar for the BKA based on German law was presumed to be lower.)

Consumers were held not to have a choice other than accept Facebook's detailed and one-sided standard terms because due to its dominant position and network effects there were no alternative social media services that provided them with a real alternative. Under these circumstances a limited form of causality between the dominant position and the behaviour harmful to competition was held to be sufficient - in so far as the latter was considered harmful, that would suffice to establish abuse. This relaxes the requirement of a causal link between dominance and the behaviour in question under German competition law. ${ }^{54}$ It also suggests that the special responsibility of dominant undertakings means types of behaviour that are unobjectionable or in any event not actionable for non-dominant firms may be out of bounds to them.

Hence the BKA prohibited the data processing policy that Facebook imposes on its users and imposed an injunction ordering termination of this conduct. The BKA decision was followed by two contrasting rulings from the Oberlandesgericht Düsseldorf ('OLG') and the federal Bundesgerichthof ('BGH') under expedited proceedings that (temporarily) left the injunction in place pending Facebook's appeal on substance. ${ }^{55}$ These judicial rulings represent opposed readings of freedom of contract for consumers.

The OLG emphasised how consumers are free to decide autonomously and based on their own preferences whether to contract in accordance with Facebook's standard terms of privacy. The OLG held it to be irrelevant whether consumers in fact rarely examined the relevant clauses for what it assumed were reasons of convenience or indifference. Yet consumers may either be rationally ignorant regarding certain information, where the costs of absorbing it are too high, or rationally apathetic where the likelihood of being able to bargain around or circumventing the terms involved by choosing other providers is too low or non-existent due to market power.

The BGH in contrast invoked consumers' rational ignorance and/or rational apathy as a condition that was influenced by Facebook's dominance and the resulting lack of alternatives for users of social networks itself. In this context it considered decisive the degree to which data were in fact surrendered in an unequal exchange under the standard terms: the BGH was confident this constituted a breach of the data protection rules. In doing so it confirmed the BKA view that the data protection rules could be invoked in establishing an abuse of dominance. ${ }^{56}$ The BGH also amplified the

\footnotetext{
54 That is Ergebniskausalität (causality derived from the results) instead of Verhaltenskausalität (causality derived from the relationship). Mohr, note 53 above, p 510.

55 OLG Düsseldorf, Decision of 26 August 2019, Case VI-Kart 1/19 (V); BGH, Decision of 23 June 2020, KVR 69/19.

56 The same finding was made in the Autorite de la concurrence and the Bundeskartellamt joint report, Competition Law and Data, 10 May 2016, p 23, citing Allianz Hungária Biztosító Zrt ao v Gazdasági Versenyhivatal, C-32/11, ECLI:EU:C:2013:160, Judgment of 14 March 2013, paras 4-47. In Asnef-Equifax, Servicios de Información sobre Solvencia y Crédito, SL v Asociación de Usuarios de
} 
BKA's finding of a parallel exclusionary abuse. The net result is that so far in Germany Facebook's private governance by means of its standard terms has been found at odds with the public rules on data and competition, although it is strictly speaking only a competition law violation - and was curtailed in fairly general terms under an injunction to cease and desist from this behaviour, without a fine.

Meanwhile as part of the appeal procedure the OLG has nevertheless suspended the BKA's decision pending Facebook's appeal, so the saga continues.

\section{The French Google Case}

By contrast, in December 2019 the French Autorité de la concurrence ('ADC') fined Google $€ 150$ million for dominance abuse in the search advertising market under Article 102 TFEU as well as the equivalent provision in Article L 420-2 of the French Code of Commercial Law. ${ }^{57}$ Google was held to have adopted opaque operating rules ('Rules') that govern the interactions between internet users and advertisers on the two-sided Google Ads advertising platform, and to have applied them unfairly and randomly to firms that purchased advertising space. Although purportedly intended to protect consumers, the Rules were found to be discriminatory and arbitrary in relation to advertisers, and therefore not fit for purpose. Given Google's extreme degree of dominance with a market share consistently above $90 \%$ and significant barriers to entry, ${ }^{58}$ and the absence of alternatives for Google Ads, the ADC held this violated Google's resulting special responsibility vis-à-vis its contracting parties.

In a further contrast to the German Facebook Case, by way of remedy the ADC also imposed not just a fine, but also a range of highly detailed injunctions on Google based on requirements to make its Rules clearly understandable and establish clear procedures for establishing violations. It also required those Rules that carried a sanction of suspension to be necessary and proportionate in relation to their legitimate objective of consumer protection.

The ADC required the criteria for identifying breaches to be objective, transparent, and non- discriminatory. ${ }^{59}$ In addition, a range of specific procedural requirements was introduced, including not only the steps and timing for qualification of a breach,

\section{(F'note continued)}

Servicios Bancarios (Ausbanc), C-238/05, ECLI:EU:C:2006:734, Judgment of 23 November 2006, para 63, the CJEU held that data issues were not a matter for competition law. Cited in Botta and Wiedemann, note 53 above.

57 Autorité de la concurrence, Decision 19-D-26 of 19 December 2019 regarding practices employed in the online search advertising sector.

58 Ibid, para 291.

59 'The list of Rules for the Protection of Internet Users for which a breach is considered serious, and for which an accelerated suspension procedure can thus be applied, must be limited to what is strictly necessary and proportionate to the objective of consumer protection. In all cases, the Rules for the Protection of Internet Users must be based on objective, transparent and non-discriminatory criteria for identifying possible breaches'. Ibid, para 568. 
but also enhanced compliance policies and the possibility for consumers to report violations.

Jointly, these requirements amount to fairness criteria for Google's private governance by means of its Rules that do not just target the formal legality of the standard terms involved but their quality and the actual manner in which Google materially applies them to its contract partners.

Regarding the business users of Google's platform these criteria are familiar from, the above-mentioned EU case law on standard terms as well as the exception of objective necessity (necessity and proportionality). ${ }^{60}$ They also recall market power based (sectoral) access regulation such as apply to for electronic communications and for standard essential patent holders who have committed themselves to FRAND license conditions. ${ }^{61}$ Moreover, the ADC designed a tailor made procedural regime that does not only impose procedural fairness for business users but is notable also for empowering consumers to directly engage with Google where advertisers were though to violate its Rules. Under this application of the EU competition rules, Google is thus held accountable to its various constituents.

\section{The App Store Investigations}

Meanwhile in 2019 and 2020 respectively, the Dutch Authority for Consumers and Markets ('ACM') and DG Competition initiated investigations of Apple's standard terms under the EU competition rules. In 2021 the CMA likewise launched an investigation into Apple in the UK following complaints that its standard terms for app developers are unfair and anti- competitive, and the ADC rejected a request for interim measures regarding advertising in mobile apps against Apple explicitly based on the BRT II framework discussed above. ${ }^{62}$

The Commission has meanwhile issued a statement of objections that contests the mandatory use of Apple's proprietary in-app purchase mechanism, which it imposes on music streaming app developers such as Spotify to distribute their apps via Apple's App Store. The Commission is also concerned about the foreclosure of

\footnotetext{
60 With reference to BRT II, note 35 above.

61 In paragraphs 349-50 the ADC references Huawei Technologies Co Ltd $v$ ZTE Corp and ZTE Deutschland GmbH, C-170/13, ECLI:EU:C:2015:477, Judgment of 16 July 2015, paras 60-71.

62 'ACM Launches Investigation into Abuse of Dominance by Apple in Its App Store' (ACM, 11 April 2019), https://www.acm.nl/en/publications/acm-launches-investigation-abuse-dominance-appleits-app-store (access: 31 March 2021); ; 'Antitrust: Commission Opens Investigations into Apple's App Store Rules', European Commission Press release, 16 June 2020, https://ec.europa.eu/commission/presscorner/detail/en/ip_20_1073; Antitrust: Commission Sends Statement of Objections to Apple on App Store Rules for Music Streaming Providers', European Commission Press release, 30 April 2021, https://ec.europa.eu/commission/presscorner/detail/en/ip_21_2061; 'CMA Investigates Apple over Suspected Anti-competitive Behaviour' (CMA, 4 March 2021), https://www.gov.uk/government/news/cma-investigates-apple-over-suspected-anti-competitive-behaviour. Autorité de la concurrence, Decision 21-D-07 of 17 March 2021 regarding a request for interim measures submitted in the sector of advertising on mobile apps on iOS, paras 139ff. English language version: https://www.autoritedelaconcurrence.fr/sites/default/files/attachments/2021-04/21d07_en.pdf
} 
cheaper alternative services as Apple applies restrictions on app developers that prevent them from informing iPhone and iPad users about these. It is focusing on at exclusion of competing apps, where Apple also has its own service-an example is music streaming with Apple Music and complainant Spotify. Jointly with the $\mathrm{ACM}$ and CMA investigations, this litigation is likely to cast further light on the approach to abusive standard terms.

\section{Fairness, Balancing, and Standards Terms in Competition Law}

In sum therefore, we see the emergence of cases applying competition law to digital platforms standard terms that complement the earlier BRT II and der Grüne Punkt case law on standard terms per se. Self-regulation and private governance is thus constrained and conditioned by means of competition law. This involves findings of specific unfair behaviour that is struck down, as in the German Facebook case. More broadly it involves fleshing out the meaning of fair treatment by a dominant undertaking both procedurally and in terms of the practical outcomes that result, as in the French Google case.

We have previously argued that the private law notion of duty of care should apply to digital platforms as a pro-active fairness requirement based on the special responsibility of dominant undertakings in their relationship to consumers more generally. ${ }^{63}$ This route will be examined in more detail below in relation to behavioural insights into standard terms and the notion of compliance by design. For now, we focus on how the proportionality standard that was previously largely applied in public law has been brought to bear on digital platforms' private governance.

Based on the above-mentioned case law, in relation to unfair standard terms we believe the control of dominance abuse will take the form of balancing tests of the interests involved according to a manifest (dis)proportionality standard. In addition, in the French Google case we have seen notions of transparent, objective and nondiscriminatory application of the relevant private governance rules, and of due process more generally, including consumer empowerment. Substantively in this case, consumers' freedom of choice was protected by lifting constraining standard terms, not by disclosing them more fully or holding consumers themselves responsible for agreeing to them. At the same time, the dominant firm was not just barred from imposing illegal standard terms, but also required to assuring the quality and even-handed application of the terms that it could impose.

This appears to represent the following three developments:

- First, attempts to apply to a digital platform an array of criteria that are familiar to courts, notably proportionality, but also transparency, objectivity and nondiscrimination. These have not yet gelled into a standard approach to private governance but their outline is clear.

63 W Sauter, 'A Duty of Care to Prevent Online Exploitation of Consumers? Digital Dominance and Special Responsibility in EU Competition Law' (2020) 8 Journal of Antitrust Enforcement 406. 
- Second, these criteria are broadly based on the implications of the special responsibility that flows from deeply asymmetric positions of market power and contractual power. Noblesse oblige, hence dominant firms must accept the consequences on their own accord, and therefore behave well proactively.

- Third, in line with the above, the findings point toward a more modern understanding of consumer behaviour. This relies less on disclosure and personal responsibility of purchasers and on ex post controls.

We argue that these developments are an expression of substantive fairness, and that proportionality in the sense of balancing of interests is at its heart. Jointly, these trends are likely to prioritise on the one hand direct public intervention and on the other a duty of care requirement for digital platforms relevant to enforcement in civil courts. Having examined the application of EU competition law to standard terms, we now turn to the relevance of the recently proposed regulation of digital markets.

\section{THE NEW REGULATORY PROPOSALS AND STANDARD TERMS}

In its February 2020 vision document on shaping Europe's digital future, the European Commission presented the green and digital transformations as the two key challenges facing the Union. ${ }^{64}$ It stated that three pillars underpin its proposals for the digital dimension: (1) technology that works for people, regarding initiatives aiming to foster trust in digital markets; (2) a fair and competitive economy, aiming to make competition instruments fit for purpose and promote a digital industrial policy; and (3) an open, democratic and sustainable society, including new rules to deepen trust in the internal market for digital services.

In December 2020, the Commission made joint legislative proposals for the Digital Markets Act that is covered by point (2) above and Digital Services Act under point (3), which concern us here. ${ }^{65}$ These proposals were made on the legal basis for internal market legislation in Article 114 TFEU and are currently before the European Parliament and Council under the normal legislative procedure of co-decision. Albeit subject to unprecedented lobbying by the undertakings concerned, it now appears that they could be adopted by the EU and implemented at national level within approximately two years.

\section{A. Fairness in the Digital Services Act}

The focus of the Digital Services Act is creating a single market for digital services. It updates the horizontal rules for online platforms in particular in relation to the e-Commerce Directive that was adopted twenty years ago, before most of today's

64 Shaping Europe's Digital Future, note 20 above.

65 Digital Markets Act and Digital Services Act, note 21 above. 
major platforms even existed. ${ }^{66}$ The core of the Digital Services Act are new rules with regard to issues such as liability for online content and online safety of users as well as due diligence obligations related to the societal risks represented by online services, jointly aiming at promoting trust and respect for human rights. The Digital Services Act covers intermediary services, internet access providers and domain name registrars, hosting services, and online platforms. Special obligations are imposed on very large online platforms, which are defined in principle as those with a monthly reach of more than 45 million EU consumers (or in any event corresponding with $10 \%$ of the Union's population). Such very large online platforms have to take special measures with regard to risk assessment, risk mitigation, data access, (advertising) transparency, compliance infrastructure, and scrutiny. As is clarified by Recital 56 of the Digital Services Act, these measures very much address concerns of private governance by very large online platforms:

In the absence of effective regulation and enforcement, they can set the rules of the game, without effectively identifying and mitigating the risks and the societal and economic harm they can cause. Under this Regulation, very large online platforms should therefore assess the systemic risks stemming from the functioning and use of their service, as well as by potential misuses by the recipients of the service, and take appropriate mitigating measures.

In the Digital Services Act, fairness is linked with transparency and accountability, and addressed in relation issues such as content moderation, online advertising, complaint handling, and dispute settlement, and a continued prohibition on general monitoring obligations. Balancing, where it is discussed in the Digital Services Act, relates to fundamental rights, not interests. The terms and conditions of online platforms are dealt with exclusively in relation to such issues, which are essentially non-economic in nature, except in the sense that they can raise barriers to economic transactions and influence innovation.

Hence its relevance to our topic is relatively limited, and in the remainder of this discussion we will focus on the Digital Markets Act. However before doing so, it is worth highlighting that in the Digital Services Act, (1) digital platforms are assigned a special responsibility for policing content that might so far have been thought a public task, and (2) very large online platforms face increased scrutiny and a higher degree of responsibility. It is these aspects with their important parallels in the Digital Markets Act that are germane to fairness and digital platforms' standard terms.

\section{B. Fairness in the Digital Markets Act}

The Digital Markets Act proposal is narrower than its counterpart as it pertains exclusively to specific unfair behaviour (which it lists in detail) ${ }^{67}$ by those digital

\footnotetext{
66 Directive 2000/31/EC of the European Parliament and of the Council of 8 June 2000 on certain legal aspects of information society services, in particular electronic commerce, in the Internal Market (e-Commerce Directive), OJ 2000, L178/1.

67 Digital Markets Act, note 21 above, Rec 13 refers to unfair business practices: 'In particular, online intermediation services, online search engines, operating systems, online social networking, video
} 
platforms that are defined as gatekeepers. These are similar to the very large platforms in the Digital Services Act but defined according to different criteria, based primarily on fixed thresholds that combine an annual EEA turnover of $€ 6.5$ billion or above and 45 million monthly end users or 100,000 yearly active business users. These are taken as indications that the platform concerned has a significant impact on the internal market, operates a core service (from a closed list of defined services) that forms an important gateway to end users for its business users, and enjoys an entrenched and durable position.

Such gatekeepers are faced with a range of ex ante obligations that prohibit for instance combining personal data sources, using data generated by business users in competition against them, and self-preferencing, as well as being required to provide platform access and data portability and to allow business users alternative ways of reaching their end users. As a last resort, the proposal enables the possibility to impose structural remedies - that is to say forced divestiture of parts of the gatekeeper's business, splitting it up.

Fairness is addressed in the Digital Markets Act in relation to platforms' business practices alongside the desire for contestable markets: the former deals with conditions and the latter with competitive capabilities. Specifically, fair and non-discriminatory terms must be applied to ranking services, and fair and non-discriminatory general conditions are required for business users' access to software applications stores (such as Apple's App Store and Google's Play Store on Android). The latter is the most explicit link to our topic, albeit a highly specific one. There are other significant links however, to do with the concept of substantive fairness that is used.

Recital 57 of the Digital Markets Act states the following with regard to fairness and standard terms:

In view of the imbalance in bargaining power between those gatekeepers and business users of their software application stores, those gatekeepers should not be allowed to impose general conditions, including pricing conditions, that would be unfair or lead to unjustified differentiation. Pricing or other general access conditions should be considered unfair if they lead to an imbalance of rights and obligations imposed on business users or confer an advantage on the gatekeeper which is disproportionate to the service provided by the gatekeeper to business users or lead to a disadvantage for business users in providing the same or similar services as the gatekeeper.

This criterion is used in Article 10 of the Digital Markets Act to determine whether by means of delegated acts additional or updated obligations must be imposed on

\footnotetext{
(F'note continued)

sharing platform services, number-independent interpersonal communication services, cloud computing services and online advertising services all have the capacity to affect a large number of end users and businesses alike, which entails a risk of unfair business practices'. We will not go into the various ways such practices are defined in antitrust and EU contract law.
} 
gatekeepers. ${ }^{68}$ An imbalance in rights and obligations or a disproportionate advantage is therefore considered unfair under the Digital Markets Act. This is in line with what we have discussed above with regard to the importance of proportionality as balancing of the relevant interests for a substantive understanding of fairness. Moreover, in the recital referenced above it is formulated specifically with regard to general conditions - in other words standard terms. As we will see below, this also reflects an element of the fairness test under the UCTD to assess whether a standard term in a B2C contract is unfair.

In addition, Recital 58 of the Digital Markets Act spells out an intended requirement of compliance by design:

The gatekeepers should ensure the compliance with this Regulation by design. The necessary measures should therefore be as much as possible and where relevant integrated into the technological design used by the gatekeepers.

So far this does not appear to be linked with specific provisions in the Regulation, although it may be assumed that in complying with Articles 5 and 6 of the Digital Markets Act the gatekeepers will have to (re)design their software in such a manner as to ensure compatibility with their obligations under the Digital Markets Act. Nevertheless, as we will discuss in our section on behavioural insights immediately below, applied to private governance through standard terms, compliance by design is a second element of substantive fairness that should be guaranteed by digital platforms.

The Digital Markets Act requires gatekeepers to submit information regarding intended mergers and submit to market investigations intended to examine systematic non-compliance with their obligations. As is the case under the general competition rules, the Commission may impose fines of up to $10 \%$ of total turnover. The Digital Markets Act complements the general competition rules based on the premise that as ex ante regulatory intervention which clearly identifies unfair practices that may in part fall outside current competition rules, it space more effective than more time-consuming individual ex post investigations. At the same time, it does not foreclose recourse to the general competition rules, because it applies in parallel.

\section{Implications for the Enforcement of EU Competition and Contract Law}

Both proposals remain to be discussed in the legislature and are likely to be amended before adoption. Having already noted the parallel application of special responsibility for very large online platforms and gatekeepers, in this short section we will focus on the Digital Markets Act. In their current form, as a list of obligations for

68 Ibid, Art 10(2) states: 'A practice within the meaning of paragraph 1 shall be considered to be unfair or limit the contestability of core platform services where: (a) there is an imbalance of rights and obligations on business users and the gatekeeper is obtaining an advantage from business users that is disproportionate to the service provided by the gatekeeper to business users; or (b) the contestability of markets is weakened as a consequence of such a practice engaged in by gatekeepers'. 
gatekeepers they appear to address specific concerns relating to standard terms for business users, in relation to app stores (Apple and Google) and online advertising services (Google), and in relation to end users concerning combining personal data from platforms and other services (Facebook). However, they do not include a general solution or approach to problems of market power regarding all digital platforms, or to all digital platforms' standard terms.

This means that the control of such terms is likely to remain a patchwork of ex ante enforcement under the new rules and ex post enforcement under EU competition and contract law. In fact, the proposal for a Digital Markets Act adds a wholly new patch because, as mentioned, it is based only on the need to promote the functioning of the internal market as set out in Article 26 TFEU, under Article 114 TFEU on the approximation of laws, and its legislative basis does not (at least so far) include the competition rules, as arguably it might well have done. ${ }^{69}$

The Digital Markets Act obviously provides remedies against breaches of its terms, including to private parties such as victims of self-preferencing. At the same time, its implications for the public and private enforcement of the competition and consumer law rules against digital platforms will be far-reaching:

- In the first place the Digital Markets Act incorporates norms on what constitutes substantive fairness that rely on balancing of interests and requires compliance by design;

- Second, and equally important, the Digital Markets Act effectively designates a set of digital platforms as super-dominant, and consequently subject to special responsibilities with regard to their counterparties, both consumers and business users.

This means that the burden of proof on private parties-as well as in public competition suits-is effectively reversed regarding such gatekeepers. In particular, proving dominance should be facilitated. This appears to lower the threshold for abuse of dominance actions against such parties significantly, and perhaps to the point where not just public but private enforcement may for the first time become an effective decentralised tool for controlling their behaviour.

The same applies by analogy for actions based on EU contract law.

This expectation might be tempered somewhat by the experience with significant market power ('SMP') regulation regarding telecommunications, ${ }^{70}$ where such an

69 Critical of this point: J Basedow, 'Das Rad neu erfunden: Zum Vorschlag für einen Digital Markets Act' (2021) 29 Zeitschrift für Europäisches Privatrecht 1. A more general discussion of the proposal is found in in Ibáñez Colomo, 'The Draft Digital Markets Act: A Legal and Institutional Analysis' (2021) 12 Journal of European Competition Law and Practice 561; and Schweitzer, 'The Art to Make Gatekeeper Positions Contestable and the Challenge to Know What is Fair: A Discussion of the Digital Markets Act Proposal'(2021) 28 Zeitschrift für Europäisches Privatrecht 503.

70 See Guidelines on market analysis and the assessment of significant market power under the EU regulatory framework for electronic communications networks and services, Communication from the Commission, OJ 2018, C159/1. These state that while SMP designations do not prejudice the application of competition law and the definition of relevant markets, the assessment of SMP should be based 
effect appears to have been limited. However, although SMP was likewise predicated upon pre-identifying dominant operators, a much more comprehensive system of market supervision was created to control them. When the SMP regime was created in 1997, private competition law enforcement was in its infancy. Moreover in the context of digital platforms a broader range of interests and more fundamental concerns are involved, including the need to safeguard democracy and the rule of law, which may give rise to greater and more effective activism.

Jointly, this restatement of the applicable norms and creation of a new basis for legal recourse may therefore be expected to be game changing, on top of the Commission's own enforcement based on the Digital Markets Act which will be a game changer in itself.

\section{EU CONTRACT LAW AND STANDARD TERMS}

\section{A. Fairness in Consumer and Customer Contract Regulation and Its Enforcement}

Together with property law, contract law provides the legal infrastructure for markets, including the EU digital internal market. Moreover, within the EU internal market, contract law has been deployed in an instrumental way. For instance, the harmonisation of contract law directly aims to achieve internal market objectives such as a high level of consumer protection. The relevant EU acts concern specific topics, for instance, product liability, unfair commercial practices, and unfair terms. ${ }^{71}$ EU contract law is different from national civil law systems in that it is not aimed at building a coherent system of contract law, but on regulating subject matters that foster the creation of the internal market. ${ }^{72}$

Within European contract law, there is a debate whether it should be limited to corrective justice, or also involve social or distributive justice. ${ }^{73}$ In this context, notions

\section{(F'note continued)}

on the same methodologies as under EU competition law. The SMP concept which was applied as a legal transplant to posts as well as healthcare in the Netherlands.

71 Council Directive 85/374/EEC of 25 July 1985 on the approximation of the laws, regulations and administrative provisions of the Member States concerning liability for defective products, OJ 1985 L210/29-33; Directive 93/13/EEC (UCTD), note 15 above; Directive 2005/29/EC of the European Parliament and of the Council of 11 May 2005 concerning unfair business-to-consumer commercial practices in the internal market and amending Council Directive 84/450/EEC, Directives 97/7/EC, 98/27/EC and 2002/65/EC of the European Parliament and of the Council and Regulation (EC) No 2006/2004 of the European Parliament and of the Council (UCPD), OJ 2005 L149/22.

72 See about this development, H Beale, Mistake and Non-Disclosure of Facts (Oxford University Press, 2012), pp 3 ff; 'European Union Law on Contracts, Chapter 2' in $\mathrm{H}$ Beale, B Fauvarque-Cosson, Jacobien Rutgers, and S Vogenauer (eds), Cases, Materials and Text on Contract Law, $3^{\text {rd }}$ ed (Hart Publishing, 2019).

73 Study Group on Social Justice in European Private Law, 'Social Justice in European Contract Law a Manifesto' (2004) 10 European Law Journal 653. See about this discussion: O Lando, 'CISG and CESL: Simplicity, Fairness and Social Justice' in L Gullifer and S Vogenauer (eds), English and European Perspectives on Contract and Commercial Law, Essays in Honour of Hugh Beale (Hart Publishing, 2014); B Lurger, 'The 'Social' Side of Contract Law and the New Principle of Regard 
such as fairness, solidarity or altruism are used in favour of redistribution. ${ }^{74}$ An argument against this position is that contract law is not an appropriate means to redistribute wealth, which should be achieved by taxes and social security systems. ${ }^{75}$ Proponents of contract law as more than corrective justice however argue that it endorses a broader interpretation. ${ }^{76}$ We agree that contract law aims at more than just corrective justice because EU contract law is in fact instrumental in achieving other goals than just corrective justice. For instance, the Directive on late payments aims at preventing bankruptcies of companies. ${ }^{77}$

In EU contract law, fairness is deployed as a legal concept. A consumer is, for instance, protected against unfair terms in business to consumer contracts and against unfair business practices. ${ }^{78}$ However, the precise meaning of fairness and commercial practice differs depending on the legal instrument concerned. For instance, fairness under the unfair commercial practices directive ('UCPD') differs from fairness under the UCTD and the P2B Regulation. Hereafter, we will discuss these three instruments. First, we will focus on their scope, the fairness test and enforcement. Subsequently, we address the notion of balancing of interests under the UCTD and the P2B Regulation.

\section{B. Policing Standard Terms by European Contract Law: Three Instruments}

In addition to competition law, the UCTD, the UCPD, and the P2B Regulation can be used to police a platform's standard terms. Their use depends on the circumstances, since the instruments' scope, the fairness tests and their implementation into the legal systems of the Member States differ.

\section{The Scope of the UCTD, UCPD, and the Online Intermediation Regulation}

First, the scope of the UCTD and the UCPD is restricted to business to consumer contracts ('B2C'), whereas the P2B Regulation concerns contractual relations between platforms, regardless of whether a platform is established within or outside

(F'note continued)

and Fairness' in A Severijn Hartkamp (ed) Towards a European Civil Code (Kluwer Law International, 2011); H-W Micklitz (ed), The Many Concepts of Social Justice in European Private Law (Edward Elgar, 2011).

74 See for instance, Hesselink, note 4 above; Lurger, note 73 above, pp 353-86.

75 J Smits, Advanced Introduction to Private Law (Edward Elgar Publishing, 2017), pp $14 \mathrm{ff}$.

76 H Collins, The European Civil Code (Cambridge University Press, 2008), p 104.

77 Directive 2011/7/EU of the European Parliament and of the Council of 16 February 2011 on combating late payment in commercial transactions, OJ 2011, L 48/1, Rec 3.

78 Directive 93/13/EEC (UCTD), note 5 above; Directive 2005/29/EC (UCPD), note 72 above; Directive 2019/2161 of the European Parliament and of the Council of 27 November 2019 amending Council Directive 93/13/EEC and Directives 98/6/EC, 2005/29/EC and 2011/83/EU of the European Parliament and of the Council as regards the better enforcement and modernisation of Union consumer protection rules (Omnibus Directive), OJ 2019 L328/7. Directive 2019/2161 must be implemented by 28 November 2021 and will apply from 28 May 2022. 
the EU, and businesses that offer their goods and services to consumers ('P2B'). ${ }^{79}$ However, the businesses involved must be established in the EU and must offer their goods or services through the platforms to consumers within the EU. If the scope of the UCTD and the online intermediation Regulation are taken together, two groups of contracts fall outside the scope of the protection of both instruments. ${ }^{80}$ They are, (1) contracts between the platform and purchasers of online goods or services who are not regarded as consumers, and (2) contracts between a platform and non-professional suppliers or sellers of online goods or services. ${ }^{81}$

Second, the UCTD only concerns non-negotiated terms in B2C-contracts. ${ }^{82}$ Although, it is not stated as explicitly, the P2B also concerns standard terms. It does not use these words, but the words 'terms and conditions' instead. ${ }^{83} \mathrm{~A}$ characteristic of such terms and conditions is that the platform sets them unilaterally, which is determined based on an overall assessment. Even if there are some negotiations between the platform and a business, the standard terms may still fall within the definition.

Third, the UCPD differs from the UCTD and the P2B Regulation, in that it does not concern contract terms directly, but commercial practices. This is a broad notion under the UCPD and includes any behaviour or omission of a business 'directly connected with the promotion, sale or supply of a product to consumers'. ${ }^{84}$

The P2B Regulation employs the notion of commercial practice. Its meaning however differs from a commercial practice under the UCPD. Under the P2B Regulation, this notion concerns standard terms which the platforms impose unilaterally upon the businesses. The wording used is similar to the provision on unfair terms in business-to-business contracts in the Commission's 2011 Draft on a Common European Sales Law ('CESL'), which was ultimately not adopted. ${ }^{85}$

79 As stated before, we will focus on the relationships involving platforms and business, since they are contracts which are usually governed by the standard terms of the platform. Regulation (EU) 2019/1150 (P2B), note 18 above, also concerns relations between search engines and corporate users, however, their relationship is not contractual and therefore we will not discuss it.

80 These contracts do fall within the scope of the Directive 93/13/EEC (UCTD), note 15 above, insofar as the end user is a consumer.

81 Iamiceli, note 5 above, pp $401 \mathrm{ff}$.

82 Directive 93/13/EEC (UCTD), note 15 above, Arts 2, 3(1)-(2).

83 On the adoption of standard in B2B contracts, see V Viglione, 'Standard Terms Incorporation in the Global Market: A Holistic Analysis' (2019) 15 European Review of Contract Law 280.

${ }^{84}$ Directive 2005/29/EC (UCPD), note 72 above, Art 2(d). See for instance, Nemzeti Fogyasztóvédelmi Hatóság v UPC Magyarország Kft, C-388/13, ECLI:EU:C:2015:225, Judgment of 16 April 2015. About fairness and the UCPD, see N Helberger, O Lynskey, H-W Micklitz, P Rott, M Sax, and J Strycharz, EU Consumer Protection 2.0, Structural Asymmetries in Digital Consumer Markets (BEUC, 2021).

85 Ibid, Rec 2; COM (2011) 635 final, Proposal for a Regulation of the European Parliament and of the Council on a Common European Sales Law, Art 86; C Busch, I Graef, J Hoffmann, and A Gawer, Uncovering Blindspots in the Policy Debate on Platform Power: Final report (European Commission, 2021), p 16. 


\section{Fairness under Three Instruments of Contract Law}

Both directives, the UCPD and the UCTD, include a fairness test that has been interpreted by the CJEU. The notion of fairness under the P2B Regulation seems less important. As it applies to contracts concluded on or after 12 July 2020, at the moment of writing, as far as we are aware there is no case law with respect to this Regulation. Hereafter we will discuss the fairness tests as included in the three instruments and their interpretation by the CJEU.

First, the UCPD polices unfair commercial practices and distinguishes three groups of unfair commercial practices. Misleading and aggressive practices are specific categories that are submitted to separate tests. ${ }^{86}$ In addition, the UCPD provides a blacklist of misleading and aggressive practices, which do not require an individual assessment of the practice at stake and are unfair a priori. Commercial practices that do not fall within the scope of misleading or aggressive practices are submitted to a general test. From the CJEU case law, it follows that only if a practice cannot be considered misleading or aggressive, the general test which concerns a practice 'contrary to the requirements of professional diligence ... materially distorts or is likely to distort the economic behaviour ... can be applied. ${ }^{87}$

In this context, Facebook's practice of offering a service for free whereas the consumers in reality pay for this by providing their data can be considered misleading under the UCPD, as the Italian Autorità Garante della Concorrenza e il Mercato did. ${ }^{88}$ In other words, the UCPD can be applied with respect to standard terms, if a business's behaviour or omission is contrary to what is written in the standard terms. This could result in an unfair practice. However, the UCPD does not directly police the content of unfair contract terms.

Second, the UCTD defines a contract term as unfair if, contrary to good faith, it results in a significant imbalance between the rights and obligations of the parties concerned. The CJEU has interpreted this test in its case law. However, terms that concern the main subject matter of the contract, such as price, do not fall within the scope of this test, but are submitted to a transparency test.

Third, in spite of its name, the P2B Regulation does not extensively rely on the notion of fairness. It is mainly concerned with transparency, which is considered a prerequisite of fairness. ${ }^{89}$ Moreover, the essential elements or the main subject matter of the contract between the platform and the business are subject to the general

\footnotetext{
86 Directive 2005/29/EC (UCPD), note 72 above, Art 5(4)-(5).

87 CHS Tour Services v Team4travel, C-435/11, ECLI:EU:C:2013:574, Judgment of 19 September 2013.

88 Botta and Wiedemann, note 53 above, p 442. See for instance, Rechtbank Noord-Holland 17 September 2014, ECLI:NL:RBNHO:2014:9422; Rechtbank Amsterdam 5 September 2017, ECLI: NL:RBAMS:2017:6652.

89 Regulation (EU) 2019/1150 (P2B), note 18 above, Rec 18; C Busch, 'The P2B Regulation (EU) 2019/1150: Towards a "Procedural Turn" in EU Platform Regulation' (2020) 9 Journal of European Consumer and Market Law 133, p 133.
} 
requirements of this Regulation, notably its transparency principle. ${ }^{90}$ Nevertheless, the Regulation aims at balancing the legitimate interests of businesses, the innovative possibilities of the platform economy, competition, and consumer choice. ${ }^{91}$ In addition, the P2B Regulation requires platforms to implement an internal complaint-handling system. ${ }^{92}$ This system must be for free for business users and is based on the principles of transparency and equal treatment. ${ }^{93}$

Thus, in the three instruments the notion of fairness differs and the terms that can be submitted to the fairness test. This has consequences for the enforcement of the three instruments.

\section{Enforcement of the Three Instruments}

The three instruments of contract law discussed above can be enforced ex ante and $e x$ post as well as privately and publicly. Ex ante enforcement of EU contract law concerns the situation in which the standard terms are drafted, but are not yet incorporated in a given contract. Ex post enforcement concerns the situation in which a contract has been entered into and the standard terms are part of a conflict between the contracting parties.

As to public enforcement, the rules in the Member States differ. For instance, independent consumer authorities in Italy and the Netherlands have the competence to enforce the UCTD and the UCPD, whereas in other Member States such as Germany they do not. ${ }^{94}$ However, this will change under Directive 2019/2161 as regards the better enforcement and modernisation of Union consumer protection rules. ${ }^{95}$ This Directive introduces penalties if businesses do not comply with the rules included in the UCTD, ${ }^{96}$ and sets out how penalties may properly be imposed. $^{97}$

The CJEU decisions on the UCTD and the UCPD concern mainly ex post enforcement of the rules both publicly and privately. With respect to the CJEU decisions on

90 The Regulation is not concerned with the issue whether standard terms have become part of the contract. That is left to the national legal systems that governs the contract between the platform and a business.

91 Regulation (EU) 2019/1150 (P2B); note 18 above, Rec 7.

${ }_{92}$ Ibid, Art 11; Busch, note 89 above, p 134.

93 Ibid, Art 11.

94 Botta and Wiedemann, note 53 above, p 442.

95 Directive 2019/2161, note 79 above, Art 7.

96 Ibid, Recs 5 ff, Art 1.

97 To impose a proper penalty, '(a) the nature, gravity, scale and duration of the infringement; (b) any action taken by the trader to mitigate or remedy the damage suffered by consumers; (c) any previous infringements by the seller or supplier, (d) the financial benefits gained or losses avoided by the trader due to the infringement, if the relevant data are available; (e) penalties imposed on the trader for the same infringement in other Member States in cross-border cases where information about such penalties is available through the mechanism established by Regulation (EU) 22017/2394 ... or (f) any other aggravating or mitigating factors applicable to the circumstances of the case' must be considered: Directive 2019/2161, note 79 above, Art 1. 
the UCTD a specific body of case law with respect to standard terms of platforms does not emerge yet. However, the standard terms of digital platforms include commonly used terms. Hence, the UCTD provisions and the rules inferred from the general case law can be applied to contracts between platforms and consumers.

In addition, platforms seem to comply voluntarily with the CJEU case law on the UCTD to a certain extent. Following the decision in VKI $v$ Amazon concerning a choice of law clause in standard terms, many platforms changed the choice of law clause in their standard terms to comply with the CJEU ruling. ${ }^{98}$

A recent example of ex ante public enforcement of contract law in the abovementioned sense concerns the standard terms of AliExpress. A number of consumer organisations filed complaints about AliExpress with their national consumer authorities in 2019. ${ }^{99}$ Among them was the Dutch Consumentenbond that filed a complaint with the Dutch Authority for Consumers and Markets. In cooperation with the European Commission and the European network of national consumer protection authorities ('CPC'), the ACM confronted AliExpress with its failure to comply with EU consumer law. As a result, in February 2021, AliExpress committed to compliance with the EU rules on consumer protection including those on standard terms in all Member States from 1 May 2021 onward. $^{100}$

Another example of ex ante public enforcement under the UCPD is the Italian Facebook case. As explained above, an omission to refer to standard terms or behaviour contrary to standard terms may result in an unfair commercial practice, as the Italian AGCM did. ${ }^{101}$

The choice between the three different instruments with respect to their enforcement depends on their scope, the tests to be applied and the competences of national consumer authorities. For instance, if the price, an essential element of the contract, is challenged, under the UCTD only the transparency test can be applied, whereas under the UCPD the test of misleading or aggressive practices may be applied. This may explain why in Italy the Facebook case was considered under the

98 Verein für Konsumenteninformation v Amazon EU Sàrl (Verein für Konsumenteninformation v Amazon), C-191/15, ECLI:EU:C:2016:612, Judgment of 28 July 2016. See for instance, Facebook.com, Terms of service, Art 4, https://www.facebook.com/terms.php; Booking.com, Terms of Service, Art 11.

99 For similar actions in other EU Member States, see 'Consumer Organisations Call for Action against Unfair Terms in Alibaba-AliExpress' Contracts with Consumers' (BEUC, 17 May 2019), https://www.beuc.eu/publications/consumer-organisations-call-action-against-unfair-terms-alibaba-aliexpress' - contracts/html ; see also in this respect ACM video services.

100 'AliExpress Informs Consumers More Clearly about Their Rights Following ACM Action' (ACM, 11 February 2021), https://www.acm.nl/en/publications/aliexpress-informs-consumers-more-clearlyabout-their-rights- following-acm-action; 'Consumer Protection: AliExpress Commits to Bringing Terms and practices in Line with EU Consumer Rules' (Daily News, 11 February 2021); EU Emergency Number 112 Marks 30th Anniversary, European Commission Press Release (11 February 2021), https://ec.europa.eu/commission/presscorner/detail/en/mex_21_527.

101 Botta and Wiedemann, note 53 above, p 442. Autorità Garante della Concorrenza e del Mercato $v$ Wind Tre SpA, formerly Wind Telecomunicazioni SpA, Vodafone Italia SpA, C-54/17-55/17, ECLI:EU: C:2018:710, Judgment of 13 September 2018. 
UCPD. In Germany it was dealt with under competition law, since in that instance the BKA did not have competence to pursue this matter under the UCPD. Other relevant aspects are the data protection component of the case, which is not a federal responsibility in Germany either, and the fact that the BKA based itself on the German competition rules, which are closer to unfair trading law than their EU equivalent.

In the following sections we will elaborate how the interests of the contracting parties and other interests are balanced under the UCTD and the P2B Regulation by discussing the fairness and transparency tests included in those measures.

\section{Balancing Interests under the UCTD}

The underlying idea of the UCTD is one of balancing as a consumer needs protection because he is in a weak position vis-à-vis the business,

as regards both his bargaining power and his level of knowledge. This leads to the consumer agreeing to terms drawn up in advance by the [business] without being able to influence the content of those terms. ${ }^{102}$

Thus, the consumer's weaker position follows both from a lack of bargaining power (asymmetrical contractual dependency) and less knowledge with respect to the content of the standard terms (information asymmetry). ${ }^{103}$ Moreover, concerning the non-binding character of an unfair term ${ }^{104}$ the CJEU held that this

is a mandatory provision which aims to replace the formal balance which the contract establishes between the rights and obligations of the parties with an effective balance which re-establishes equality between them .... ${ }^{105}$

\section{The UCTD Case Law on Fairness}

The UCTD includes a fairness test to assess whether a standard term in a B2C contract is unfair. ${ }^{106}$ From the relevant CJEU case law it can be inferred that the fairness test has three elements and a fair standard term must meet each requirement. The consequence of an unfair term is that it is not binding under the UCTD. ${ }^{107}$

\footnotetext{
102 See for instance, Océano Grupo Editorial SA v Roció Murciano Quintero and Others, C-240/ 98-C-244/98 ECLI:EU:C:2000:346, Judgment of 7 June 2000; Pohotovost' sro v Iveta Korckovská, C-76/10, ECLI:EU:C:2010:685, Judgment of 16 November 2010; DF Asbeek Brusse, $K$ de Man Garabito v Jahani BV, C-488/11, ECLI:EU:C:2013:341, Judgment of 30 May 2013; Banca B Sa v $A A A$, C-269/19, ECLI:EU:C:2020:954, Judgment of 25 November 2020.

103 Commission Notice, Guidance on the interpretation and application of Council Directive 93/13/ EEC on unfair terms in consumer contracts, OJ 2019, C323/4.

104 Directive 93/13/EEC (UCTD), note 15 above, Art 6(1)

105 Pohotovost'sro v Iveta Korckovská, note 102 above.

106 Directive 93/13/EEC (UCTD), note 15 above, Art 3(1). About this test, see Collins, note 11 above, pp 245 ff.

107 Directive 93/13/EEC (UCTD), note 15 above, Art 6.
} 
The CJEU decisions with respect to the fairness of a standard term concern online and offline situations, but unlike in EU competition law where there is an emerging body of case law with respect to standard terms of digital platforms specifically, no such body of specific case law exist in contract law yet. ${ }^{108}$ However, the standard terms of digital platforms include commonly used terms which concern inter alia exclusion of liability, modification of standard terms, forum choice and choice of law. Therefore, the UCTD provisions and the rules inferred from the general case law can be applied to contracts between platforms and consumers.

In Aziz, the CJEU held that the Article 3(1) UCTD unfairness test includes two elements: a good faith requirement and an imbalance-test. ${ }^{109}$ A bank had provided Mohammed Aziz with a loan which was secured by a mortgage to buy a house. Aziz stopped paying the loan's instalments and under the standard terms of the loan and/or mortgage contract he had to pay interest for late payment, which he did not pay either. After the bank had sold Aziz's home for 50\% of its value, Aziz was evicted from his home. One of the preliminary questions was whether the clause in the standard terms that set the annual default interest if the debtor failed to pay at $18.75 \%$, was an unfair term. To answer that question the CJEU formulated the two above-mentioned tests:

- A term is contrary to good faith if an average consumer would not have agreed to the term, had the parties negotiated about the term in that situation.

- A term is unbalanced if in the case of a comparison between the law applicable in the absence of the term in the contract and the term itself, the consumer would be worse off by applying the term included in the standard terms. ${ }^{110}$

From these two tests, it can be inferred that different interests are balanced. The good faith test reflects classic contract law, since the presumption seems to be that negotiations result in a fair outcome. So, if the parties had negotiated about the term's content and would have agreed upon it, the term can be considered fair. The imbalance test refers to rules of national contract law that would have been applicable if the term had not been agreed upon. In that case, the balancing done by a legislator when she drafted the legislation is considered to be fair based on the democratic process by which such rules are established.

\footnotetext{
108 Following the 2007 financial crisis, many decisions concerning loan and mortgage agreements between a consumer/house owner and a bank. A bank may in some ways be compared to a digital platform, as some banks are considered to be essential within the financial ecosystem. In this respect a bank could be compared to a platform that also is a gatekeeper. However, from the CJEU case law it cannot be inferred that those banks have specific responsibilities from a consumer perspective.

109 M Aziz v Caixa d'Estalis de Catalunya, Tarragona i Manresa (Catalunyacaixa), C-415/11, ECLI: EU:C:2013:164, Judgment of 14 March 2013.

110 See about this test, F Paolo Patti, 'Personalized Unfair Terms Control: EU Law Meets Innovative US doctrines' (2020) 6 European Review of Private Law 1249, p 1257; about this test and platforms, B Hajek, 'Online Platform Service Providers on Platform 93/4: A Call for an Update of the Unfair Contract Terms Directive' (2020) 5 European Review of Private Law 1143.
} 
It must be emphasised however that terms that concern the main subject matter of the contract, such as price, do not fall within the scope of these two tests. ${ }^{111}$ However, the price and other 'main subject matters' of the contract are submitted to the transparency test, which is the third element of the fairness test. ${ }^{112}$

\section{The UCTD and Transparency}

The transparency principle set out in the UCTD ${ }^{113}$ requires a term to be in 'plain, intelligible' language. ${ }^{114}$ Apart the requirement that a given term must be grammatically correct, an average consumer must be able to foresee its economic consequences taking into account the contractual framework. ${ }^{115}$ The average consumer is someone "who is reasonably well-informed and reasonably observant and circumspect'. ${ }^{116}$ It is this less intrusive test to which price and other main subject matter of the contract is submitted. ${ }^{117}$

In addition, the CJEU has deduced from the transparency principle and the preamble ${ }^{118}$ of the UCTD ${ }^{119}$ that a trader must provide the standard terms to the consumer prior to the conclusion of the contract. ${ }^{120}$ This has two purposes: it

111 Directive 93/13/EEC (UCTD), note 15 above, Art 4(2). See about fair prices and the UCTD, M Hesselink, 'Unfair Prices in the Common European Sales Law' in Gullifer and Vogenauer (eds), note 74 above, ppt 225-36.

112 Directive 93/13/EEC (UCTD), note 15 above, Art 4(2). The UCTD does not define the main subject-matter of a contract. The CJEU answered preliminary questions in this respect in: Kásler $v$ Jelzálogbank, note 16 above.

113 Directive 93/13/EEC (UCTD), note 15 above, Arts 5, 4(2).

114 See about the transparency test, B Matei, IO Matei v SC Volksbank România SA, C-143/13, ECLI: EU:C:2015:127, Judgment of 26 February 2015; Jean-Claude Van Hove v CNP Assurances SA, C-96/ 14, ECLI:EU:C:2015:262, 47, Judgment of 23 April 2015; Collins, note 11 above, pp 247 ff; M Loos, 'Transparency of Standard Terms under the Unfair Contract Terms Directive and the Proposal for a Common European Sales Law' (2015) 23 European Review of Private Law 179; H-W Micklitz and N Reich, 'The Court and Sleeping Beauty: The Revival of the Unfair Contract Terms Directive (UCTD)' (2014) 51 Common Market Law Review 771, pp 786 ff.

115 EOS KSI Slovensko sro v J Danko, M Danková, C-448/17, ECLI:EU:C:2018:745, Judgment of 20 September 2018; OTP Bank Nyrt, OTP Faktoring Követeléskezelö Zrt v T Ilyés, E Kiss, C-51/17, ECLI: EU:C:2018:750, Judgment of 20 September 2018; Profi Credit Polska SA v others, C-84/19-C-222/ 19-C-252/19, ECLI:EU:C:2020:631, Judgment of 3 September 2020.

116 Kásler v Jelzálogbank, note 16 above.

117 Ibid.

118 Directive 93/13/EEC (UCTD), note 15 above, Rec 20.

119 Ibid, Arts 4(2), 5.

120 Nemzeti Fogyasztóvédelmi Hatóság v Invitel Távközlési Zrt, C-472/10, ECLI:EU:C:2012:242, Judgment 26 April 2012; RWE Vertrieb AG v Verbraucherzentrale NRW eV, C-92/11, ECLI:EU: C:2013:180, Judgment of 21 March 2013; Constructora Principado v JI Menéndez Álvarez, C-226/12, ECLI:EU:C:2014:10, Judgment of 26 January 2014. 
serves the aim of informing the consumer; and it enables the consumer to file the standard terms so that he can determine his rights and obligations if something goes wrong. 121

The transparency test is linked to discussion about disclosing information to empower the consumer. Consequently, the information must be comprehensible both from a linguistic and economic perspective. However, the CJEU takes the average consumer as the benchmark, which is problematic from a behavioural perspective, as will be discussed further below.

\section{Balancing Interests under the P2B Regulation}

The P2B Regulation aims at promoting fairness and transparency in relations between platforms and businesses that offer their goods and services to consumers. ${ }^{122}$ It does so by establishing 'a fair, predictable, sustainable, and trusted online business environment within the internal market' by mandatory rules. ${ }^{123}$ This is considered necessary, because platforms have significantly more bargaining power than ordinary businesses, which they may use to impose practices upon such businesses that are contrary to good commercial practice, good faith and fair dealing. ${ }^{124}$ Moreover, it is considered crucial that platforms behave responsibly in establishing this business environment. ${ }^{125}$ This Regulation is relevant to our discussion not only because it represents one leg of the triangular relationship between digital platforms, businesses and consumers, but also because it deals specifically with platforms and standard terms.

\section{Transparency under the Regulation}

The Regulation uses the notion of transparency both as a means to prevent unfair behaviour by platforms ${ }^{126}$ and to provide predictability to business users. ${ }^{127}$ Hence, the platforms' standard terms must meet certain requirements that can all

121 Content Services Ltd v Bundesarbeitskammer, C-49/11, ECLI:EU:C:2012:419, Judgment of 5 July 2012; Directive 2000/31/EC (e-Commerce Directive), note 67 above, Art 10(3); Directive 2011/83/EU of the European Parliament and of the Council of 25 October 2011 on consumer rights, amending Council Directive 93/13/EEC and Directive 1999/44/EC of the European Parliament and of the Council and repealing Council Directive 85/577/EEC and Directive 97/7/EC of the European Parliament and of the Council Text with EEA relevance, OJ 2011 L304/64, Rec 23.

122 As stated before, we will focus on the relationships involving platforms and business, since they are contracts which are usually governed by the standard terms of the platform. Regulation (EU) 2019/1150 (P2B), note 18 above, also concerns relations between search engines and corporate users, however, their relationship is not contractual and therefore we will not discuss it.

123 Regulation (EU) 2019/1150 (P2B), note 18 above, Rec 7.

124 Ibid, Rec 2.

125 Ibid, Rec 3.

126 Ibid, Rec 18.

127 Ibid, Rec 15. 
be linked to transparency, ${ }^{128}$ as the relevant provisions concern duties to disclose information in the platform's standard terms in plain and intelligible language.

Article 3 of the Regulation sets out the main transparency requirements. As regards basic transparency, the platform's standard terms must be set out in plain and intelligible language and be easily available at all (pre-)contractual stages. Moreover, this provision requires the platform's standard terms to include specific information. For instance: (1) the standard terms must explain the reasons upon which a platform can suspend, terminate or restrict the service to a business; (2) platforms must inform business of changes in the standard terms within a reasonable time before they will be changed; and (3) the business must have the possibility to terminate the contract before the end of the notice period. Standard terms which do not meet these requirements are void. These effects do not only apply with respect to the contracting parties, but are erga omnes and ex tunc. ${ }^{129}$

Other provisions include information disclosure duties for the platform as to their standard terms. ${ }^{130}$ However, the rationale of those disclosure duties seems to differ. For instance, the disclosure of parameters with respect to ranking aims at predictability for businesses, ${ }^{131}$ whereas fair competition and consumer choice are the reasons for transparency with respect to differentiated treatment between the platform's own goods and services and the business' goods and services. ${ }^{132}$ Yet the Regulation does not include a remedy if the platform fails to disclose the relevant information. It is left to the legal systems of the Member States to impose measures that are effective, proportionate and dissuasive.

The transparency test in the Regulation is elaborated (1) with respect to ranking of services and goods by business users, (2) preferred treatment of the goods and services offered by the platform itself or business controlled by the platform, and (3) the termination, suspension, or restriction of a particular business user on the platform. Its provisions on retroactive changes and termination uses the words good faith and fair dealing, but the meaning of good faith and fair dealing is not made clear: arguably each contract between a platform and a business is governed by these requirements. However, again the consequences are left to the legal systems of the Member States.

\section{Remedies under the Regulation}

As to the policing of standard terms in the contract between the platform and a business, the Regulation only provides a remedy to those mentioned in Article 3: nullity of the contract term concerned. In this respect a business is protected vis-à-vis a platform. This protection is restricted to transparency, and there is no other fairness test to

\footnotetext{
128 Ibid, Arts 3, 5, 6, 7, 9, 10; Iamiceli, note 5 above, pp $404 \mathrm{ff}$, argues that the Regulation deals with both unfair commercial practices and unfair contract terms.

129 Regulation (EU) 2019/1150 (P2B), note 8 above, Rec 20.

130 Ibid, Arts 5, 6, 10

131 Ibid, Art 5, Recs 24, 26.

132 Ibid, Art 7.
} 
which the platform's standard terms are submitted. Yet, it is questionable whether all the information that is to be included in the platform's standard terms in fact protects those businesses. First, the remedies are left to the legal systems of the Member States. Second, behavioural studies in the area of consumer transaction show that the more complex a contract is, the less likely it is to be understood by the consumer. As we will discuss this in the section on behavioural studies and standard terms, this probably also applies to small and medium sized businesses.

In spite of its title, therefore the notion of fairness is not developed in this Regulation. ${ }^{133}$ Instead fairness is so far exclusively filled in by the prerequisite of transparency.

\section{COMPARISON BETWEEN EU COMPETITION AND CONTRACT LAW}

\section{A. The Balancing Tests}

On the one hand, fairness as a concept appears to be in ascendance both within EU competition and contract law. On the other hand, as we have seen, fairness as a form of balancing is so far used as an effective substantive test more in EU competition law and the Digital Markets Act than in contract law. Within EU contract law itself there are also notable differences.

- The UCTD, the B2C instrument employs a fairness test to assess whether a term is unfair and non-binding. This test has three elements—-good faith, significant imbalance, and transparency — and each element represents a different balancing test. The first two elements of the fairness test under the UCTD do not apply to the essential elements of a contract, for instance, the price. However, these are submitted to the transparency test.

- The P2B Regulation seems so far to be limited to a transparency test. Although balancing is suggested by its language about the superior bargaining power of platforms, transparency appears to be key. Arguably a contract between a platform and a business is subject to good faith and fair dealing requirements, the Regulation does not elaborate what this entails.

In contract law we therefore notice a range of standards that at first sight appear to be fairness -and balancing-based, but are in fact at least partly based primarily on the less restrictive notion of transparency. The difference between businesses and consumers, B2C and P2B, and therefore between the two sides of the multi-sided markets involved, may well go some way in explaining this anomaly. However, this contrasts to comparable recent sectoral regulation on $\mathrm{B} 2 \mathrm{~B}$ outside the realm of digital platforms such as Directive 2019/633 on agribusiness and food which does include a substantive fairness requirement. ${ }^{134}$ Nor is this distinction found in competition law,

133 Cf Iamiceli, note 5 above, pp 404 ff.

134 Directive (EU) 2019/633, note 18 above. 
where $\mathrm{P} 2 \mathrm{~B}$ and $\mathrm{P} 2 \mathrm{C}$ relationships are both subjected to a similar if not identical fairness standard based on balancing. Moreover, arguably in their relationship with a platform, many businesses are faced with information-asymmetry, asymmetrical contractual dependency and market power and consequently are in a position very similar to that of consumers.

There is so far little formal traction for the idea that in a balancing exercise under contract law the degree of market power should play a distinct role. Yet where market power exists there will always be asymmetric contractual dependence. Hence, enforcement priorities in contract law lead to a comparable approach: the contracting practices of parties with market power are focused upon more often. ${ }^{135}$ As discussed above, it may be modified further by the ex ante designation of gatekeepers in the Digital Markets Act, which will facilitate both public and private enforcement against them in both EU competition and contract law. If this is indeed the case, then we are likely to see further convergence and cross-pollination between EU competition and contract law, partly via regulation.

\section{B. Choice of Instrument between Competition and Contract Law, and Within Contract Law}

With respect to the choice of instrument for enforcement, competition law, the UCPD or UCTD, the scope of the tests in the legislative instrument involved and the competences of the consumer authorities are relevant. They often explain why a certain route has been chosen.

- For example, under German law, the BKA does not have competence to enforce the UPCD, nor is there an independent authority to enforce consumer law. The UCPD's enforcement is left to, inter alia, consumer organisations and chambers of industry and commerce. ${ }^{136}$ This explains why the Facebook under German law was tackled under competition law even although this involves a higher standard of proof, and under Italian law under the arguable lower bar of the UCPD - possibly also due to less strict enforcement of the data protection rules than in Germany.

- Under the UCTD, the price of a product or a service is not submitted to the general fairness test of good faith and balancing the parties' interest, but merely to a transparency test. This may explain why the AGCM preferred to deal with payment by data under the UCPD rather than under the UCTD.

Hence, a combination of institutional design and related practical considerations are likely to influence enforcement decisions. Finally, as we have already mentioned above, the designation of gatekeepers by the proposed Digital Markets Act is likely to promote more effective public and private enforcement both in EU competition and contract law.

135 Graef and van Berlo, note 12 above.

136 Botta and Wiedemann, note 53 above, p 440. 


\section{STANDARD TERMS AND BEHAVIOURAL SCIENCE}

\section{A. Behavioural Competition Law and Standard Terms}

Although the study of behavioural competition law includes an analysis specifically of standard terms ${ }^{137}$ it remains an emerging field, also with regard to digital platforms. ${ }^{138}$ The general concern of behavioural competition law is that because consumer biases can weaken competition, firms are likely to exploit such biases. They can do so for instance by tying and bundling services, by individualised price discrimination supported by algorithmic decision making, by competing for active customers while overcharging inactive customers, and by foreclosing and overcharging in aftermarkets after offering low up-front prices. Profit maximising schemes can also deliberately facilitate consumer error by obfuscating their terms through complexity. ${ }^{139}$

In fact, behavioural exploitation cannot readily be solved by competitive process because it tends to become a parameter of competition itself, especially where the gains of educating consumers cannot be appropriated effectively. ${ }^{140}$ This leads to a bleak vision where competition by a 'confusopoly' may entail results that are suboptimal even to those of a monopoly. ${ }^{141}$ Such exploitation of biases leads to consumers making suboptimal choices from an individual perspective that not only amount to exploitation. It also promotes customer lock-in that frustrates freedom of choice and excludes competitors at the same time. And it facilitates a transfer of the consumer surplus to the producers. Hence features such as the excessive complexity of consumer contracts hurt not only the consumer, but also the competitive process and consumer welfare in general. ${ }^{142}$

This problem appears to be amplified in a digital platform context, where consumers are isolated from each other, at an extreme disadvantage in terms of the available data, meaningful comparisons are difficult to make, and alternatives are in any event hardly available. Tying and bundling of services may be reinforced by status quo bias, with the resulting lock-in frustrating contestability. The German Facebook Case and possibly the App Store cases involve such a narrative. Fairness may also be compromised as consumers choose based on what is most salient (such as upfront price or quality), and ignore restrictive terms and conditions, transfer of personal data and lock-in effects.

\footnotetext{
137 O Bar-Gil, Seduction by Contract: Law, Economics, and Psychology in Consumer Markets (Oxford University Press, 2012); Bar-Gil, note 22 above.

138 Mathis and Tor, note 22 above; A Tor, 'The Market, the Firm and Behavioral Antitrust' in Zamir and Teichman, note 22 above, p 539-67; A Reeves and M Stucke, 'Behavioral Antitrust' (2011) 86 Indiana Law Journal 1527; Issue on Behavioral Antitrust (2019) 1 CPI Antitrust Chronicle.

139 Mathis and Tor, note 22 above.

140 Bar-Gil note 22 above, pp 468-71.

141 Mathis and Tor, note 22 above; K Kalayci, 'Confusopoly: Competition and Obfuscation in Markets' (2016) 19 Experimental Economics 299.

142 Bar-Gil, note 22 above, pp 475-76.
} 
At the same time behavioural competition law still accords value to competition and therefore competition policy, and has implications for possible solutions as well. To some extent competition law will be able to take account of the effects of consumer biases, for instance in its market definition and dominance analysis, as well as in the design of remedies. Bounded rationality in terms of status quo and default bias in relation to digital platforms has been identified as a concern in EU law as early as the 2004 Microsoft browser remedy designed to activate user choice, and again in the remedies in the EU's Google cases where status quo bias was identified as a major driver of the abuse. ${ }^{143}$ Taking the role of information intermediaries into account in competition policy enforcement is another possible avenue.

Regarding the role of regulation, regulators as repeat players with institutional resources, investigating powers at their disposal, are likely to be better positioned and less bias-prone than consumers. In this sense the Digital Markets Act may promote fairness in the area of digital platforms' standard terms as well. Finally, the law on unfair contract terms may be one way of helping to ensure that competition delivers good consumer outcomes. ${ }^{144}$ Although it is one of the key assumptions of this article that this is indeed the case, as we will see below consumer law faces its own struggles in the light of behavioural constraints. Hence it may require more proactive measures on account of digital platforms, such as compliance by design.

\section{B. Behavioural Consumer Law and Standard Terms}

Behavioural consumer law mainly focuses on whether regulation and its interpretation by the courts, in particular with respect to transparency, can guide human behaviour and consequently is effective. ${ }^{145}$ This research is particularly relevant in the case of ex post control of standard terms under EU contract law. It seems less relevant in the case of ex ante control of such terms by means of collective action. ${ }^{146}$ Another relevant aspect of behavioural consumer law is how the law could police the use of consumer biases by digital platforms in their algorithms. From a contractual behavioural perspective there seems to be less research into this. ${ }^{147}$

In the literature, the use of the average consumer as a benchmark is widely criticised on the basis of behavioural insights. In the UCTD the concept of the 'average consumer' is not codified, but the CJEU introduced this concept as a yardstick with

\footnotetext{
143 A Fletcher, 'The EU Google Decisions: Extreme Enforcement or the Tip of the Behavioral Iceberg?' (2019) 1 CPI Antitrust Chronicle 14.

144 Ibid.

145 See for instance, O Seizov, A Wulf, and J Luzak, 'The Transparent Trap: A Multidisciplinary Perspective on the Design of Transparent Online Disclosures in the EU' (2019) 42 Journal of Consumer Policy 149; T Wilkinson-Ryan, 'The Perverse Consequences of Disclosing Standard Terms' (2017) 103 Cornell Law Review 117. About contracting behaviour, see S Becher and E Unger-Aviram, 'The Law of Standard Form Contracts: Misguided Intuitions and Suggestions for Reconstruction' (2010) 8 DePaul Business \& Commercial Law Journal 199.

146 Empirical research as to consumer behaviour in the case of ex ante policing seems to be very scarce.

147 See about this issue, Calo and Rosenblatt, note 24 above.
} 
respect to the good faith and the transparency test. ${ }^{148}$ The concept of the average consumer resembles the homo economicus and because behavioural science has demonstrated that the average consumer does not in fact exist, using the average consumer as a benchmark is questionable. The seller's or supplier's disclosure duty prior to the conclusion of the contract is based on this notion of an average consumer. Although this is now generally accepted as a myth, ${ }^{149}$ the CJEU still presumes that the average consumer reads this information and enters into a contract well- informed.

Empirical studies show that the vast majority of consumers never read standard terms before they enter into a contract. ${ }^{150}$ As a result, alternative solutions have been offered, such as the use of rankings or symbols to warn the consumer. Moreover, if consumers would read the standard terms, they will not understand them, since they are often incomprehensible. ${ }^{151}$ Yet other empirical studies suggest that plain and comprehensible terms do play a role in a later phase, in particular in the case of conflicts between the contracting parties. ${ }^{152}$ Firstly, consumers do seem to read the standard terms in this phase, and secondly, plain and intelligible information may empower consumers cognitively. If they understand a text better, consumers are more likely to inquire with the seller or supplier if there is a problem. This also affects the ex post control of standard terms which may be deemed transparent and fair if designed as such.

Fairness by design is a category that is being asserted and developed in modern theories on economic approaches to consumer law. ${ }^{153}$ However, this principle is

\footnotetext{
148 See about the average consumer as a yardstick, Schebesta and Purnhagen, note 16 above.

149 O Ben-Shahar, 'The Myth of the "Opportunity to Read" in Contract Law' (2009) 1 European Review of Contract Law 1.

150 Y Bakos, F Marotta-Wurgler, and D R Trossen, 'Does Anyone Read the Fine Print? Consumer Attention to Standard Form Contracts' (2014) 43 Journal of Legal Studies 1; O Ben-Shahar and C Schneider, 'The Failure of Mandated Disclosure' (2011) 159 University of Pennsylvania Law Review 647. Z J Eigen, 'Experimental Evidence of the Relationship between Reading the Fine Print and Performance of Form-Contract Terms' (2012) 168 Journal of Institutional and Theoretical Economics (JITE) 124. Otherwise, Becher and Unger-Aviram, note 145 above, p 215, who argue on the basis of experimental research that consumers scan or read parts of the standard terms before they enter into the contract.

151 U Benoliel and S Becher, 'The Duty to Read the Unreadable' (2019) 60 Boston College Law Review 2256; F Marotta-Wurgler and R Taylor, 'Set in Stone? Change and Innovation in Consumer Standard-Form Contracts' (2013) 88 New York University Law Review 240. For a different perspective, B Schmitz and C Pavillon, 'Measuring Transparency in Consumer Contracts: The Usefulness of Readability Formulas Empirically Assessed' (2020) EuCML 191.

152 See about reading and post-contractual phase, Becher and Unger-Aviram, note 145 above, pp 206 ff; W van Boom, P Desmet, and M van Dam, “'If It's Easy to Read, It's Easy to Claim” - The Effect of the Readability of Insurance Contracts on Consumer Expectations and Conflict Behaviour' (2016) 39 Journal of Consumer Policy 187; see about transparency and post-contractual phase, A Wulf and O Seizov, 'The Principle of Transparency in Practice: How Different Groups of Stakeholders View EU Online Information Obligations' (2020) 28 European Review of Private Law 1065.

153 See Chapter 7, 'Fairness by Design: The Introduction of a Positive Duty to Trade Fairly' in P Siciliani, C Riefa, and H Gamper, Consumer Theories of Harm: An Economic Approach to Consumer Law Enforcement and Policy Making (Hart Publishing, 2019).
} 
already found in the EU data protection rules, and, as we have seen, in the proposal for a Digital Markets Act. Thus, Article 25 of the General Data Protection Regulation requires data protection by design and default, ${ }^{154}$ and Recital 68 of the proposal for a Digital Markets Act (cited above) likewise spells out a compliance by design requirement.

Jointly, this suggests that private governance should made be fair by design and behaviour- proof by actively avoiding the exploitation of biases and promoting the use of nudges of average consumers in the right direction (including defaults), as well as cognitive empowerment of consumers by informing them in a comprehensible manner. Certain consumer authorities and financial market regulators have already started demanding this more broadly in relation to unfair commercial practices. ${ }^{155}$

\section{CONCLUSION}

In this article, we have looked both at (1) consumers and (2) business users/purchasers in their relation to (3) digital platforms. Our aim was to establish whether there is convergence in control of private governance by means of standard terms could be based on the developing fairness norms in EU competition and contract law; if so, whether these norms could be enforced effectively, and what behavioural modifications are required from digital platforms.

In this context identifying a workable standard for fairness in private governance was key. The findings that we have presented above, which are necessarily preliminary on further research, are that this can plausibly be done by defining fairness in this context as predicated upon (1) balancing and (2) a duty of care that involves compliance by design. Both are proactive duties that reflect the special responsibility of the undertakings involved, and they can jointly be framed as an expression of accountability. For effective accountability to occur, the application of these requirements should be made explicit, so they can be tested.

\section{A. Fairness and Proportionality: Balancing of Interests}

The correction of a structural imbalance between market parties, which forms the basis of both abuse of dominance law and consumer law in this area, is to do with balancing.

\footnotetext{
154 Regulation (EU) 2016/679 of the European Parliament and of the Council of 27 April 2016 on the protection of natural persons with regard to the processing of personal data and on the free movement of such data, and repealing Directive 95/46/EC OJ 2016, L119/ 1. Its Recital 78 states, inter alia: 'In order to be able to demonstrate compliance with this Regulation, the controller should adopt internal policies and implement measures which meet in particular the principles of data protection by design and data protection by default'.

$155 \mathrm{Cf}$ 'Guidelines Protection of the Online Consumer: Boundaries of Online Persuasion $(A C M, 11$ February 2020), https://www.acm.nl/en/publications/guidelines-protection-online-consumer.
} 
Therefore, it is in line with the core of proportionality - the balancing of interests. In this case, its reason is the correction of market power. The dominant parties have to do this balancing themselves and are vetted on that basis.

From the case law we derive rules on digital platforms demonstrating sequentially (1) the necessity of a legitimate objective for the standard terms, as well as (2) the balancing of the interest involved, and (3) to apply due process, in other words a proportional application of their terms. However, these norms are more pronounced in EU competition law than in EU contract law, as is the focus on market power. EU contract law by contrast places more emphasis on the less stringent norm of transparency.

\section{B. Fairness and Behavioural Propriety: The Duty of Care}

We believe the implications of the above-mentioned insights from behavioural science relate primarily to the notions of duty of care and compliance by design. Previously, we have already argued in favour of the former. ${ }^{156}$ Compliance by design is now being developed in modern theories of economic approaches to consumer law, ${ }^{157}$ and more broadly can be found in regulatory frameworks such as the General Data Protection Regulation ('GDPR') and the proposal for a Digital Markets Act.

In order to become behaviour proof, private governance rules established as standard terms should encourage: (1) consumer/purchaser biases not being exploited; (2) the use of possible nudges, such as appropriate defaults in the context of standard terms; and (3) cognitive empowerment of consumers/purchasers to overcome biases.

This can be linked to the balancing requirement that we discussed earlier, as it would redress the market power and informational balance between the parties involved. It can also be linked to a duty of care and to compliance by design as positive duties to act in order to avoid damaging the interests of the contracting parties-notably consumers and customers - by digital platforms. As positive duties they are required of the dominant party, whose behaviour and private governance - the standard termsshould be vetted based both on EU competition and contract law on that basis.

\section{Practical Tests}

We propose giving the concept of fairness a specific meaning in the context of applying competition and contract law to digital platforms' standard terms that has a very

\footnotetext{
156 Sauter, note 63 above. Here the following five principles were proposed as pre-emptive behavioural remedies: (1) protect your consumer: use the relevant consumer data to screen also for the consumers downside and use this information to the consumer's benefit; (2) no negative discrimination: do not treat a consumer differently in order to exploit their inferior information position or lack of outside options; (3) apply transparency: be clear about the consumer's risks in the transaction, their outside options, and how the choices offered to them compare to those of others; (4) provide a fair non-choice outcome: use smart default settings that ensure consumers reach a normally low risk outcome if they do not actively pursue an individual choice; and (5) take responsibility for results: apart from procedural compliance there should be substantive compliance documented by actual performance.

157 Siciliani, Riefa, and Gamper, note 153 above.
} 
practical dimension. Linking fairness to proportionality and compliance by design introduces requirements of balancing and appropriate proactive behaviour that enable the use of existing legal tests. Greater reliance on the special responsibility of dominant companies leads to testing for illegal conditions based on the standards of necessity for a legitimate objective and adequate balancing of interests, as well as due process. The behavioural insights mentioned imply qualitative requirements of effective form and content. This dovetails with the demand that a duty of care is observed: compliance by design should not just be implemented but actively improved upon.

\section{Enforcement}

Both EU competition and contract law can be enforced ex post and ex ante, as well as publicly and privately. With respect to public enforcement both the scope of the instruments and the competences of especially national consumer authorities appear to explain the choice of instrument to policy digital platforms' standard terms. This suggests a need for more coordination between enforcement of anti-trust rules and rules of contract law, or more integration of such enforcement where it is located with a single consumer law and competition authority at national level.

\section{E. The Relevance of Regulation}

Finally, there is nevertheless a broad-based view that further asymmetrical controls are needed, which check for market power. The targeted regulation for gatekeepers which the European Commission has recently proposed in the Digital Markets Act is in line with this demand. By reversing the burden of proof in relation to the existence of market power that requires additional checks, this regulation will reinforce both public and private EU competition and contract law enforcement. Jointly this is likely to lead to a further dynamic development of this area of law that may help to establish greater fairness in private governance. 